\title{
SEXUAL CONSENT AS VOLUNTARY AGREEMENT: TALES OF "SEDUCTION" OR QUESTIONS OF LAW?
}

\author{
Lucinda Vandervort*
}

This article proposes a rigorous method to map the law on to the facts in the legal analysis of sexual consent using a series of mandatory questions of law designed to eliminate the legal errors often made by decision makers who routinely rely on personal beliefs about and attitudes toward "normal sexual behavior" in screening and deciding cases. In Canada, sexual consent is affirmative consent, the communication by words or conduct of "voluntary agreement" to a specific sexual activity, with a specific person. As in many jurisdictions, however, the sexual assault laws are often not enforced. Reporting is lowest and non-enforcement highest in cases involving the most common type of assailants, those who are not strangers but instead persons the complainant knows, often quite well—acquaintances, supervisors or coworkers, and family members. Reliance on popular narratives about "seduction" and "strangerdanger" leads complainants, police, prosecutors, lawyers, and trial judges to truncate legal analysis of the facts and leap to erroneous conclusions about consent. Wrongful convictions and perverse acquittals, questionable plea bargains and ill-considered decisions not to charge, result. This proposal is designed to curtail the impact of prejudgments, assumptions, and biases in legal

* Professor of Law, University of Saskatchewan; B.A., Bryn Mawr College; M.A., Ph.D., McGill University; J.D., Queen's University (Kingston, Ont.); LL.M., Yale Law School. Research for this article was supported by the College of Law Endowment Fund, University of Saskatchewan, the President's SSHRC Fund, and the Borden Ladner Gervais Research Fellowship Program. The article benefited from my discussions about "seduction" with my colleague, Michael Plaxton, and the work done by Jared Biden, third-year J.D. candidate at the University of Saskatchewan, who reviewed the case law and commented on an earlier draft of the article. All these contributions are gratefully acknowledged. The usual caveats apply.

New Criminal Law Review, Vol. I6, Number I, pps I43-20I. ISSN 1933-4192, electronic ISSN 1933-4206. (C) 2013 by the Regents of the University of California. All rights reserved. Please direct all requests for permission to photocopy or reproduce article content through the University of California Press's Rights and Permissions website, http://www.ucpressjournals.com/reprintInfo.asp. DOI: I0.I525/nclr.20I3.I6.I.I43. 
reasoning about voluntariness and affirmative agreement and to produce decisions that are legally sound, based on the application of the rule of law to the material facts. Law has long had better tools than the age-old and popular tales of "ravishment" and "seduction." Those tools can and should be used.

Keywords: Sexual assault, rape, consent, seduction, Canadian criminal law, legal reasoning, judicial decision-making, prosecutorial discretion, charging decisions, police decision-making

The traditional approach to rape and sexual assault cases leaves most of the crucial decisions to be determined by the world view supplied by dominant social attitudes, myth, and custom, not by law. Thus, social attitudes cause not only the problem itself_rape and sexual assault_but also ensure that the legal system will fail to enforce its own laws. ${ }^{1}$

\section{INTRODUCTION}

In jurisdictions worldwide, sexual assault law in theory and sexual assault law in action are not always the same. ${ }^{2}$ In Canada, there is often a wide gap between the law on the books as interpreted by the Supreme Court of Canada and its interpretation and enforcement at the grassroots level by police, prosecutors, and lower court judges in sexual assault cases. ${ }^{3}$ As

I. Lucinda Vandervort, Mistake of Law and Sexual Assault: Consent and Mens Rea, 2:2 Can. J. Women \& L., 233, 263 (1987-1988).

2. Gender violence is an international problem, with common themes and experiences as well as the unique features that specific legal systems and cultural traditions present. Many jurisdictions have high levels of sexual violence and low levels of reporting and prosecution. The analysis presented in this article may be of use, directly or indirectly, in other jurisdictions where efforts are underway to address sexual violence as a violation of human rights. Recent international studies documenting the breadth and severity of the problem include: U.N. Women, Progress of the World's Women 2oil-2oi2: In Pursuit OF Justice 46-63 (2OII), http://progress.unwomen.org/pdfs/EN-Report-Progress.pdf; World Health Org. \& London Sch. of Hygiene and Tropical Med., Preventing Intimate Partner and Sexual Violence Against Women: Taking Action and Generating Evidence I2-I5 (2010), http://www.who.int/violence_injury_prevention/publications/violence/9789241564007_eng.pdf; Corinna Seith, Joanna Lovett, \& Liz Kelly, Different Systems, Similar Outcomes?: Tracking Attrition in Reported Rape Cases in Eleven Countries (2009).

3. The gap is seen in victimization surveys of alleged incidents versus reported cases and in attrition as cases progress through the criminal justice system. Three surveys, conducted 
a result, there is a widespread lack of public confidence in the response of the criminal justice system to sexual violence, and proportionately few sexual assaults are reported to the police. Potential complainants are not confident they can expect more protection by the legal system from sexual violence than their mothers and aunts enjoyed. ${ }^{4}$

In addition, research shows that although most sexual assaults are committed by someone known to the assailee, ${ }^{5}$ nonstranger assaults are the least reported and prosecuted form of sexual assault. ${ }^{6}$ As a consequence, the

between 1993 and 2004, show less than Io\% of alleged sexual assaults were reported to police. "Founding" rates are lower than for other types of offenses. Since 1994, only $42 \%$ of the cases labeled by police as "founded," i.e., substantiated, resulted in charges. Of the "founded" cases, $11 \%$ led to a conviction. The Statistics Canada 2004 victimization survey found 460,000 incidents of sexual assault with I,406 convictions. Accordingly, the attrition rate from alleged incident to conviction is estimated at $99.7 \%$. Holly Johnson, Limits of a Criminal Justice Response: Trends in Police and Court Processing of Sexual Assault, in SeXual Assault In Canada: Law, Legal Practice \& Women's Activism (Elizabeth Sheehy, ed., 20I2).

4. Anecdotal evidence. See Johnson, supra note 3, text at nn.I7, I8. Lack of confidence in the response of the Canadian justice system to sexual violence is widespread and well documented; see Sheehy, ed., supra note 3, passim.

5. Samuel Perreault \& Shannon Brennan, Criminal victimization in Canada, 2009, Sept. 28, 20I0, JURISTAT (Statistics Canada, Canadian Centre for Justice Statistics, Catalogue no. 85-002-X, vol. 30, no. 2. (modified)), http://www.statcan.gc.ca/pub/85-002-x/2010002/ article/II34O-eng.htm reports: "In over half (51\%) of sexual assault incidents, the perpetrator was a friend, acquaintance, or neighbor of the victim, compared to $29 \%$ of robberies and $31 \%$ of physical assaults. ... The majority of sexual assaults were not reported to the police (88\%) (Table Io)." Samuel Perreault, Violent victimization of Aboriginal people in the Canadian provinces, 2009, March II, 20II, JURISTAT, http://www.statcan.gc.ca/pub/85-002-x/ 20IIOoI/article/II4I5-eng.htm, reports: "Both Aboriginal and non-Aboriginal victims of non-spousal violence often know their perpetrator. In 2009, $68 \%$ of Aboriginal victims and $52 \%$ of non-Aboriginal victims were victimized by a relative, a friend, an acquaintance, a neighbor or another person known to them (Table 4)." Comparisons among groups are now available for 2010: see Maire Sinha, Family Violence in Canada: A Statistical Profile, 20IO, Statistics Canada, May 22, 20I2, JURISTAT, http://www.statcan.gc.ca/pub/85-002-x/ 20I200I/article/II643-eng.pdf. Interpreting statistics requires caution; categories used for reporting have changed recently; statistics based on police reports only capture offenses that are reported to police and recorded. General Social Surveys are based on self-reports and include unreported alleged offenses. See Holly Johnson \& Myrna Dawson, Violence Against Women in Canada: Research and Policy Perspectives (20ii).

6. A nonexhaustive list of sources includes: Teresa DuBois, Police Investigation of Sexual Assault Complaints: How far have we come since Jane Doe?, in Sheehy, supra note 3; T. Hattem, Highlights from a Preliminary Study of Police Classification of Sexual Assault Cases as Unfounded, I4 JusT Res. (July 3I, 2009), http://canada.justice.gc.ca/eng/pi/rs/rep-rap/jr/ jri4/p9.html; Z. Peterson \& C. Muelenhard, Was It Rape? The Function of Women's Rape 
enforcement gap is largest with respect to sexual assault offenses allegedly committed by acquaintances and family members (nonstrangers) even though the identity of the assailant in these cases clearly is known. This is not a new development. Historical evidence shows that nonstranger sexual assault has long been an under-recognized and underacknowledged category of sexual violence in Canada. ${ }^{7}$ Yet Canadian law requires affirmative sexual consent to all sexual activity, not merely between strangers. Sexual consent is defined as the communication, by words or conduct, of "voluntary agreement" to a specific sexual activity, with a specific person. Agreement must be expressed and "voluntary" to be legally effective. " "When it's not 'YES!' and VOLUNTARY, it's 'NO!" and "When it's 'NO!' it's 'NO!'” In theory, this is all quite clear and beyond question. Nonetheless, some decision makers in the Canadian criminal justice system fail to implement even the weaker " $N O$ ' means 'NO'” standard.

This article analyzes the cultural and legal basis of the gap between "law on the books," as interpreted by the Supreme Court of Canada, and "law in action" at the grass roots and in the lower courts in sexual assault cases, and concludes that the root cause is a collective failure to follow the rule of law. In particular, the legal requirement that consent be voluntary and affirmative is often ignored, and as a result many decisions about what does and does not constitute sexual assault are not based on the law but on traditional cultural paradigms, especially stock stories about "seduction" and "enticement." The enforcement gap with respect to assaults by nonstrangers appears to result from the influence of cultural paradigms and stock

Myth Acceptance and Definitions of Sex in Labeling their Own Experiences, 5I(3/4) SEX Roles I29 (2004); J. DuMont, K. Miller, \& T. Myhr, The Role of 'Real Rape' and 'Real Victim' Stereotypes in the Police Reporting Practices of Sexually Assaulted Women, 9(4) Violence Against Women 466 (2003); Tina Hattem, Survey of Sexual Assault Survivors, at I3, I5, I9 (Canada Dept. of Justice, 2002); R. Bachman, The Factors Related to Rape Reporting Behavior and Arrest: New Evidence from the National Crime Victimization Survey, 25:I Crim. Just. Behav. 8 (1998); R. Gartner \& R. Macmillan, The Effect of Victim-Offender Relationship on Reporting Crimes of Violence Against Women, 37:3 Can. J. Criminology 393 (1995).

7. Constance Backhouse, Carnal Crimes: Sexual Assault law in Canada I900-I975 (2008).

8. Criminal Code, RSC 1985, c C-46, s 273.I. See Lucinda Vandervort, Affirmative Sexual Consent in Canadian Law, Jurisprudence, and Legal Theory, 23:2 Colum. J. Gender \& L. 395 (2012), for a detailed examination of the development of the law of affirmative sexual consent in Canada since the early 1980s. A brief overview as of 2012 appears below. 
narratives about so-called "normal sexual behavior" on how decision makers-from complainants, police, and prosecutors, to judges and jurorsthink and talk about sexual activity and sexual assault. Starting with the complainant, these paradigms, narratives, and related patterns of thought and speech invite each decision maker, in turn, to truncate the process of legal analysis and leap to conclusions based on nonlegal factors. The effects include failure to report offenses and failure to enforce the law.

The article is organized in two parts. Part I analyses the problem in the Canadian context. Representative scenarios are examined within the framework provided by current Canadian law, culture, and public discourse to identify the practices used in legal reasoning that permit cultural paradigms and narratives based on the concept of "seduction" and related assumptions and attitudes about "normal sexual behavior" to affect conclusions about voluntariness and affirmative agreement in the actus reus of sexual assault. Part II turns to solutions and proposes specific changes in the practices jurists routinely use to structure legal analysis of consent or "voluntary agreement" in the actus reus of sexual assault.

Part II proposes that trial judges presiding in sexual assault cases be required to determine, as a question of law, whether there is sufficient evidence of the actual communication of voluntary agreement for a defense of consent to be available, and whether the circumstances of the offense are consistent with the legal prerequisites of voluntariness in the complainant. A ruling that finds either (I) insufficient evidence of affirmative consentthe communication of voluntary agreement - for the defense of consent to be available in law, or (2) the circumstances established by the evidence were inconsistent with the legal prerequisites of voluntariness, would establish the absence of consent for purposes of proof of the actus reus. Judges who failed to rule on these issues and instead simply presumed that the complainant communicated agreement and that her words and conduct were voluntary, would thereby err in law, rendering the decision subject to appeal. Judicial adoption of this approach, together with some related trial practices, detailed below, would curtail the impact of cultural paradigms and stock narratives on legal analysis of consent in the actus reus of sexual assault, and result in decisions based on application of the rule of law to the facts. Scenarios used in Part I to illustrate the influence of the seduction paradigm in legal decision making are revisited in Part II to demonstrate the operation and effect of the proposed practices in legal analysis of the evidence in typical sexual assault cases. 
This article addresses issues arising in relation to sexual consent but arguably has broader relevance. Gaps between "law on the books" and "law in action," are not uncommon in law, especially when formal law conflicts with cultural norms and practices. Patterns of thought and speech like those used in relation to sexual assault and nonenforcement of sexual assault laws often shape nonsexual interactions between individuals who are not equal in social power, even though they may be formally "equal" in law. Some of the institutional barriers to effective enforcement of the rule of law in those contexts are similar to those that impede enforcement of the sexual assault laws. The rule of law and the law of consent are central to liberal democracies in theory; in practice, the roles of law and consent are routinely undermined by deeply embedded cultural habits of assuming entitlement and deferring to power. "Normal" social behavior, like the "normal" sexual behavior examined in this article, often presumes consent and claims compliance with the rule of law when, in actuality, there is neither. The steps required to address those issues in the context of the nonenforcement of sexual assault laws arguably suggest steps that could be taken to address similar impediments to the practical implementation of other laws.

\section{OUTLINE AND ANALYSIS OF THE PROBLEM}

A. Sexual Assault under Canadian Law

The Canadian Criminal Code is a federal statute. ${ }^{9}$ Parliament and the Supreme Court of Canada create law that binds the entire country. The Supreme Court of Canada is the final judicial arbiter in matters of criminal law. On December 12, 199I, the federal Department of Justice tabled Bill C-49, a comprehensive set of amendments to the sexual assault provisions of the Criminal Code. In the form enacted by Parliament five months later, the Bill included a Preamble setting out the objectives of the legislation, a provision curtailing use of evidence of complainants' sexual history, a detailed codification of the definition of consent, and statutory bars codifying limits on the use of the defense of belief in

9. Provincial legislatures may enact "quasi-criminal" legislation that includes limited punitive measures for the purpose of enforcing laws enacted to regulate activities and issues within provincial jurisdiction; criminal law, as such, is within the exclusive jurisdiction of the federal government. 
consent. ${ }^{10}$ Representative cases decided at common law show that when the decision or judgment in a sexual assault or common assault case dealt with the issue of consent, the term was used to refer to a voluntary choice or free act of volition by a person who appreciates the situation and the risks inherent to it, and is not subject to coercion. ${ }^{11}$ The definition of "consent" enacted by Parliament in 1992 largely codified the common law definition of "consent." 12 In 1997, the Criminal Code was further amended to limit the use of complainants' personal records at trial. ${ }^{13}$

Under current Canadian law, a conviction for sexual assault requires proof beyond a reasonable doubt that the accused committed the actus reus with the necessary mens rea. The actus reus of sexual assault is the touching of a person who does not consent in circumstances of a sexual nature. ${ }^{14}$ To be legally effective, both at common law and as codified by section 273.I of the Criminal Code, consent must be voluntary, communicated by the words or conduct of a person with legal capacity. In addition, subsection 265(3) of the Criminal Code lists circumstances-including submission by reason of force, fear, threats, fraud, or the exercise of authority-under which the law will deem consent to be absent, despite a complainant's ostensible consent or participation. ${ }^{15}$ The complainant's reason for ostensibly consenting by complying or participating does not need to be either reasonable or communicated to the accused in order for consent to be vitiated for the purposes of proof of the actus reus. The validity of consent in the actus reus depends on the complainant's subjective state of mind toward the touching at the time it took place.

Io. Bill C-49, An Act to Amend the Criminal Code (sexual assault), S.C. I992, c.38, as passed by the House of Commons, June I5, 1992 (effective Aug. I5, 1992). The Preamble is not reproduced in the Criminal Code, but affects statutory construction of the provisions and must be considered when constitutional issues are raised. See Vandervort, Affirmative Consent, supra note 8, at 4I2-I3, for the Preamble and substantive provisions of the Act.

II. See Vandervort, Affirmative Consent, supra note 8, at 407-II, on "consent" in Canadian common law.

I2. R. v. Esau, [1997] 2 S.C.R. 777, dissenting reasons by MacLachlin J., as she then was. The relationship of the common law and statute law defining sexual consent is discussed in Vandervort, Affirmative Consent, supra note 8, at n.27.

I3. Bill C-46, An Act to Amend the Criminal Code (Production of Records in Sexual Offence Proceedings), S.C. 1997, c.30, enacting ss.278.I-278.9I to the Code.

I4. R. v. Chase, [1987] 2 S.C.R. 293.

I5. Criminal Code, R.S.C. 1985, c.C-46, s.265(3). 
The complainant's testimony is the only source of direct evidence of her state of mind. The accused may claim that the complainant's words and conduct at the time of the offense provided a basis to infer that she did want the sexual touching to take place or, at least, a basis for reasonable doubt about the credibility of her assertion that subjectively she did not want the sexual touching to take place. But if the trier of fact concludes that the evidence proves that the complainant did not subjectively consent, the absence of consent is proven, even though her conduct, in whole or part, may be inconsistent with that conclusion. This may occur, for example, when her objectively observable words or conduct are not voluntary. The absence of any evidence of words or conduct that communicate affirmative consent or voluntary agreement to the activity, as, for example, when a complainant is silent or passive, conclusively establishes the absence of consent for the purposes of proof of the actus reus. ${ }^{16}$ Submission is not consent. ${ }^{17}$

"Consent" functions differently in the context of the actus reus and mens rea of the offense. For the purposes of the actus reus, "consent" means that the complainant not only communicated agreement by her words or conduct but also did so voluntarily; that is, subjectively, in her own mind, she actually did want the sexual touching to take place. The complainant's state of mind is crucial in relation to voluntariness, but her words and conduct are the means by which agreement is communicated. In the context of mens rea, the term "consent" refers to objectively observable words or conduct by the complainant that affirmatively communicate her voluntary agreement or consent to engage in the sexual activity in question with the accused at the time in question.

The mens rea of the accused with respect to the issue of consent is governed by the common law and provisions of the Criminal Code. ${ }^{18}$ To assert that the complainant consented is to assert a belief in consent. If the belief in consent is based on a mistake about the law of consent-for example, the belief that "no" means "yes," or that silence is consent, or that failure to resist, or resist successfully, is consent-the defense of belief in consent is not available. Pursuant to the common law and section ig of the

I6. R. v. M. (M.L.), [1994] 2 S.C.R. 3. See Vandervort, Affirmative Consent, supra note 8, at $4 \mathrm{I} 5-\mathrm{I} 6$ for further discussion of these issues.

17. Vandervort, Affirmative Consent, supra note 8, at .415-16.

I8. Id. 
Criminal Code, ignorance of the law is not an excuse and does not exculpate an accused. If the alleged belief purports to be based on a mistake about the facts, there must be evidence of the facts that allegedly provided a basis for the mistaken belief. Any words or conduct by the complainant that are alleged to have affirmatively communicated voluntary agreement to engage in the activity in question will be material and relevant and must be considered. When there is no support, or insufficient support, in the evidence for the allegedly mistaken perception of the complainant's words or conduct as the communication of agreement, the defense of belief in consent is not available and therefore may not be considered by the trier of fact. Furthermore, the accused's belief in consent may not be reckless, willfully blind, or accompanied by an awareness of any of the circumstances listed in subsection 273.I(2) under which the law deems there to be no consent. These circumstances include express refusal by the complainant to engage in the activity or to continue with it, consent by a third party, the complainant's incapacity to consent, and abuse of a position of trust, power, or authority to induce the complainant to engage in the activity. Section 273.I(3) provides that the circumstances in which no consent is obtained are not limited to those specified under section 273.I(2). ${ }^{19}$

\section{B. Thought, Speech, Culture, and Law}

Propagandists and balladeers, evangelists and advertising executives have long known that rhetoric can be used strategically to shape cultural attitudes, beliefs, and practices. Rhetoric is linked to cognition; commonly used phrases and sayings reflect and shape the legal consciousness of ordinary citizens and the deliberation processes of decision makers within the criminal justice system. Slogans encapsulating information about the legal definition of sexual consent and sexual assault must therefore be crafted with the same purposeful care used to create any tool; if they are poorly designed they may simply reinforce traditional assumptions, beliefs, and attitudes that have long shaped the sexual behavior of individuals and the decisions made in sexual assault cases by police, prosecutors, and judges.

Slogans designed to inform the Canadian public about sexual assault law are a case in point; they have already proven to be quite unruly. The slogan "NO' means 'NO"' is widely used by activists and educators in Canada,

19. For a detailed introduction to Canadian sexual consent law, see id. 
but can be misleading and ultimately regressive in its practical effects insofar as it suggests there is no offense in the absence of resistance. By contrast, "When It's Not 'YES!' and VOLUNTARY, It's 'NO!?" focuses attention on the requirement for affirmative sexual consent, the actual communication of voluntary agreement to sexual contact. The impact of these slogans and the cultural paradigms and approaches to legal reasoning associated with them on the legal analysis of typical sexual assault scenarios, illustrates the strategic role rhetoric can and often does play as a tool to shape both ordinary sexual conduct and legal reasoning and decision making in sexual assault cases. Words matter, not in and of themselves, but because of their effects.

Some scholars and activists may assume that the influence of rhetoric and cultural paradigms on ordinary behavior and legal reasoning is so strong that the gap between law on the books and law in action will remain until there is a new sexual culture and "new normal sexual behaviors" supported by new rhetoric more in tune with the law. This article argues that such an approach is defeatist; it avoids the crucial legal task-the development of tools that in combination can be effective to enforce the sexual assault laws now, not merely at a distant and indefinite point in the future. We already have laws and legal norms that in theory protect individual rights of sexual self-determination. This article proposes specific steps designed to secure more reliable interpretation and effective implementation of those laws. The development and widespread social acceptance of cultural and behavioral norms that are less in conflict with legal norms is not a prerequisite for correct interpretation and application of sexual assault laws as long as the power of the distinctions between cultural and legal norms, and civil society and the legal system is appreciated and used effectively. ${ }^{20}$

Effective implementation of the approach proposed here will require many legal professionals to reexamine their assumptions about the laws, facts, and the questions that must be addressed and resolved in analyzing and disposing of a sexual assault case. That is a good thing. Traditional

20. Cultural norms do shape political priorities and affect decisions about the allocation of state resources required to enforce the law, however. The positive duty of the state under domestic and international law to protect persons under its jurisdiction from sexual assault, and conflicts between human rights norms and those given priority by domestic justice systems are relevant. See Lucinda Vandervort, Legal Subversion of the Criminal Justice Process? Judicial, Prosecutorial, and Police Discretion in Edmondson, Kindrat, and Brown, Chapter 6 in Sheehy, supra note 3, at II3-53. 
approaches are defunct. The time for widespread recognition of this reality by police, prosecutors, defense counsel, and judges is already long overdue. Leadership by judicial councils and law societies may be required to address those aspects of these issues that require changes in judicial practices and redefinition of the duties of counsel.

\section{Thought, Speech, and "Normal"/"Seductive" Sexual Behavior}

There is some resistance in popular culture, in the media, and among some members of the legal profession and even the judiciary, to the changes in sexual behavior that are required to give practical effect to equality rights. Resistance and backlash commonly take the form of ridicule that uses the specter of social paralysis to discount the feasibility and desirability of any approach to sexual consent that is inconsistent with what is described as "normal sexual behavior," sex as "usual" on the "usual" terms. ${ }^{21}$ Similar patterns of resistance to sociolegal change are found in popular culture and reported in the academic literature in Canada and the United States. ${ }^{22}$ Discussion of affirmative consent requirements, in particular, often elicits

2I. Don Stuart, Ewanchuk: Asserting 'No Means No' at the Expense of Fault and Proportionality Principles, 22 C.R. (6th) 39(1999), text at n.23, observes that in 1992 when legislation to amend the sexual assault provisions of the Criminal Code was under discussion, "[ $t$ ]here were strongly stated opinions in newspaper editorials that Parliament was to criminalize seduction and that sexual conduct would now require advanced consent in writing." For further examples and discussion of media reaction to the Ewanchuk case, see Joanne Wright, Consent and Sexual Violence in Canadian Public Discourse: Reflections on Ewanchuk, 16:2 CAN. J.L. \& Soc'y I73 (200I).

22. Many authors published in the United States conclude that affirmative consent requirements are not feasible. See Susan Caringella, Addressing Law Reform in Law and Practice 79-82 (2009); Symposium on Rape, Affirmative Consent to Sex, and Sexual Autonomy, 4I:4 Akron L. Rev. 839 (2008); David P. Bryden, Forum on the Law of Rape: Redefining Rape, 3 Buff. Crim. L. Rev. 317 (2000); Stephen Schulhofer, Unwanted Sex: the Culture of Intimidation and the Failure of Law (1998). Similarly, extensive media commentary ridiculed the student-drafted Antioch College Sexual Offense Policy, Oct. 4, 1993. The policy reflected keen awareness of practical issues related to implementation of affirmative sexual consent requirements and included detailed guidance on a range of pertinent issues. Antioch students were understandably irritated by the media frenzy and widespread misrepresentation of the policy. The Antioch Board of Trustees approved a revised policy on June 8, 1996. The revision of Jan. I, 2006, reviewed the history of the development of the policy. The current Sexual Offense Prevention Policy, 2012-2013 STUdent HANDBOoK 36-38, is available at http://antiochcollege.org/assets/pdf/studenthandbook.pdf. 
the opinion that the communication of consent has no place in "normal" sexual behavior. ${ }^{23}$ Explicit agreement to sexual activity is seen as discordant, disruptive, and undesirable, and it is widely assumed that anyone can always "just say 'No'," as if that were the end of the matter. Collectively these views underscore the link between thought and speech, cognition and rhetoric, and the stubborn tenacity of "folk-ways." 24 Despite those views, sometimes stridently expressed, sexual assaults by nonstrangers, including spouses, partners, family members, and acquaintances, remain not only the most common type of sexual assault but also the least likely to be reported and prosecuted. Either few complainants are saying anything, let alone "No," or they are not being heard. Meanwhile, sexual assault remains a serious problem.

"Seduction," rather than "voluntary agreement," is treated as the convenient, though ill-defined, archetype for so-called "normal" sexual behavior. ${ }^{25}$ Seduction has long been the common stock of the romance novel and appears central to the manner in which many Canadians view sexual encounters. One leading legal commentator regrets that developments in interpretation of sexual assault laws leave no place for what he describes as "border-line cases" involving the nonconsensual sexual touching and ambiguous communication commonly referred to as "sexual seduction."26 His perception about the law "on the books" as interpreted by the Supreme Court of Canada is entirely correct. Nonconsensual sexual touching is sexual assault; such behavior renders the aggressor liable to be convicted even if the touching is accompanied by ambiguous communication about consent. But it is also clear that interpretation and application of the law "on the ground," at the grass roots, and in many of the lower courts, have not caught up with the law enacted by Parliament and interpreted by the Supreme Court of Canada. Examination of the case law and patterns of

23. This reaction is arguably symptomatic of what is profoundly problematic about the concept of so-called "normal" sexual behavior.

24. J.C. Marsh, A. Geist, \& N. Caplan, Rape and the limits of Law Reform IO7 (1982) (alluding to Summer's assertion that "Stateways cannot change Folkways.").

25. Wendy Larcombe examined rape narratives and concluded that the ideal of romantic love depicted in fiction likely has a firm grasp on the cultural imagination and the fantasies of legions of loyal readers, precisely because it is a foil for the everyday social facts of heterosexual exchange; Wendy Larcombe, Compelling Engagements: Feminism, Rape Law and Romance Fiction 39 (2005). Its appeal is as an escape from "normal" as experienced by the typical female reader, who knows the difference between fantasy and fact all too well.

26. Stuart, supra note 2I, at 39. 
reporting and enforcement confirms that "seduction" remains an influential paradigm. It retains a central place in public and professional legal consciousness, and shapes both sexual conduct and legal decisions in cases involving sexual activity between persons who knew one another-nonstrangers. ${ }^{27}$ Part of its popular appeal appears to be its convenient ambiguity. Based on the available evidence, there can be little question but that the dynamics of "seduction," and common beliefs and attitudes toward it, do often play a role in decisions not to report or prosecute sexual assaults.

At this point we have established that: (I) "seduction" is used by many Canadians as an interpretative framework for thinking and talking about sexual activity, and continues to be the subject of favorable comment in Canadian legal literature; (2) most sexual assaults in Canada involve acquaintances and family members, i.e., nonstrangers; (3) the vast majority of sexual assaults by nonstrangers are never reported to police; and (4) comparatively few such complaints lead to convictions. Less clear, as yet, is whether and how these phenomena are related to one another. The concept of "seduction" is used in ordinary everyday discourse to describe the dynamics of social encounters and, on occasion, to express social approval, acceptance, or in some circumstances, condemnation. Beliefs about seduction, and attitudes toward those who engage in it or are affected by it, are openly acknowledged as influences in some decisions about whether and when it is appropriate to invoke a criminal law response to assaultive sexual conduct. The ease with which sexual assault is interpreted as "seduction" may indeed explain much under-reporting and nonenforcement. But before we can hope to understand how, by what mechanisms characterizing or describing behavior as "seductive" affects social judgments and legal decisions, we need to clarify what is ordinarily meant by the term "seduction."28

27. See Melanie Randall, Sexual Assault Law, Credibility, and Ideal Victims': Consent, Resistance, and Victim Blaming, 22 CAN. J. Woman \& L. 397 (2010) [hereinafter, Randall, Credibility]; Jessica Derynck, Lacking Context, Lacking Change: A Close Look at Five Recent Lower Court Sexual Assault Decisions, i4 Appeal: Rev. Current L. \& Legal Reform io8 (2009) [hereinafter, Derynck, Lacking Change]; Elaine Craig, Ten Years After Ewanchuk the Art of Seduction is Alive and Well: An Examination of the Mistaken Belief in Consent Defence, Can. Crim. L. Rev. 247 (2009) [hereinafter, Craig, Ten Years]; Melanie Randall, Sexual Assault in Spousal Relationships, Continuous Consent, and the Law: Honest But Mistaken Judicial Beliefs, 32:I Manitoba L.J. I44 (2008) [hereinafter, Randall, Spousal Assault].

28. The following discussion of the term "seduction" is based on the author's experience as a participant-observer in Western culture and her analysis of the common usage of the term. 


\section{Seduction}

"Seduction" is commonly used to refer to the process of inducing or enticing someone to do or agree to do something that, but for the seduction, she or he would not or might not do. By definition, seduction is not coercion or compulsion. Seduction uses positive reinforcement, the offering of something that is desired, to persuade; duress, coercion, or compulsion uses negative reinforcement, the threat of something that is feared, to persuade. In both seduction and duress, however, the subject or target exercises "free will" and makes a "choice" that is not dictated by the circumstances. In seduction, the premise is that the subject could have refused to "give in to temptation or desire." In duress, the subject could have "confronted his or her fear" and refused to comply with the demand. Thus in both cases, the action taken by the subject is described as "a choice" and attributed to the subject, who retains full agency and is taken to be responsible for the choice she or he made.

In seduction, the choice made by a seducee may or may not be one a prudent rational person might make in the whole of the circumstances. In addition, the activity may or may not be something one or both parties "should not" do because of either conflicting commitments or social mores. The term is used in a wide variety of contexts in which persuasion often has a role, from sex to politics, business to advertising. Furthermore, the term often has a subtle quasi-sexual connotation because seduction in any context is understood to play on the subject's "desire" for "pleasure," and at least in the present time, "pleasure" itself has a sexual connotation. The term may also be used, however, to characterize a nonsexual interaction as one in which persuasion by inducements "causes" the seducee to want to do something she or he would otherwise not do. Seduction, as such, does not necessarily involve physical contact. Words alone may suffice.

In a sexual context, "seduction" refers to: (I) the emotional, psychological, cognitive, and psycho-sexual effects of social interaction between two persons who are attracted to one another and who, through the seduction process, move from being acquaintances toward a more intense, often intimate, sexual relationship; (2) the conscious purposeful use of charm, flattery, gifts, blandishments, and attention to persuade or cajole (or, when viewed more negatively, manipulate and deceive) another person to look favorably on you, be attentive to you, spend time with you, and do what you ask them to do, including engaging in, or at minimum tolerating, 
sexual activity with you; or (3) the effect of one person's charm, attractiveness, charisma, intelligence, prowess, and the like, on another person, even though one or both parties are or may be partially or entirely unconscious of those effects. Seduction and seductive conduct may be evaluated either positively or negatively and described in terms that mirror that judgment.

Whether a seduction is deemed worthy of social approval or disapproval generally depends on social judgments about: (I) the aggressor/initiator's intentions, purposes, or objectives; 2 ) the net effect of the seduction on the well-being of the target/mark/seducee; or (3) both of these factors. A sexual seduction, of any of the three types above-mutual, manipulative, or de facto and ad hoc-may or may not end well, in a scenario in which "everyone lives happily ever after." Judged in hindsight in a case where it produces a good outcome, seduction is seen as a process that secured spiritual as well as psychological, physical, and social benefits to both parties. Here sexual attraction is seen as a positive force leading to a positive outcome-a true union of minds or souls, one might say. Any acts of manipulation or deception that were used in the course of the seduction are then retrospectively deemed to be benign, rather than malevolent, or are simply forgotten because the outcome is assessed positively.

A relationship that originates in a mutual seduction may lose vitality over time and or cease to be mutual, potentially leaving one or both parties bereft. Seduction is commonly viewed in a negative light if deceit and manipulation are used by one party to control the other party for ulterior purposes, to gain benefits that are not reciprocal, or if the other party suffers negative or harmful consequences. Literature and mythology are full of characters, famous and infamous for their seductive exploits, who exemplify the traits of good will, loyal service, and nurturing beneficence on the one hand, or deceit, theft, and exploitation on the other. Their "mark," "victim," "soul mate," or "dearly beloved," as the case may be, are also often typecast, stock figures - the nature and extent of their net spiritual and material gains or losses being largely a function of the socioeconomic arrangements and ideals of the day. Contemporary social circumstances are different from those of the nineteenth century or of classical Greece and Rome, but the characterizations of individuals in terms of their presumed intention and motive, and the impact their actions have on others, remain quite similar. Seduction remains one of the principal psycho-social mechanisms that give rise to the interpersonal entanglements and internal psychological conflicts between reason, emotion, and instinct 
that perennially characterize comedy and tragedy. Tales of seduction mirror common human hopes and fears, temptations and conflicts.

In many sexual encounters, seduction is used to deflect responsibility for one party's sexual choices and sexual activity to the other party. Below, this characteristic is demonstrated to be of crucial significance in the legal construction of responsibility in sexual assault cases. In seduction, the seducee exercises "free will" and makes "autonomous choices" in response to desire. In a mutual seduction, moreover, each party is both the seducer and the seducee. Each party explains his/her response to, or infatuation with, the other person, by pointing to the endearing or inflaming characteristics of the other and then using the language of cause and effect to explain his or her own choices made in response. This is especially useful when attempting to explain choices that were arguably imprudent. Desire for the other is experienced as "caused by" the other and commonly presumed to be mutual - sometimes wistfully, with fond hope, rather than accurately; but often each party assumes him- or herself to be the "cause" of what is presumed to be the other party's desire. This is a trap. Those who touch first and ask later, if at all, may sincerely believe he or she is acting precisely as the other party wishes them to act because the one who initiates the touching assumes/believes the desire he or she feels is mutual. This is the tale many sexual offenders tell. Some offenders say they were doing the complainant a "favor" by doing exactly what the offender "knew" the complainant wanted/needed the offender to do. ${ }^{29}$

The concept of "seduction" serves a rich variety of social and legal functions in large part precisely because of its inherent imprecision and ambiguity. Once the bare possibility of mutuality is raised, it is easily surmised that each party may have enticed and persuaded the other. Typically, both parties will be assumed to have used some sort of enticement or inducement to influence the other party. Exactly who is the initiatoraggressor and who is the mark or target quickly becomes quite unclear, and the question of who touched whom first without consent is lost from view. Few such cases proceed. Assailants who are perceived as well-

29. Anecdotal evidence. See also Lorenne Clark \& Debra Lewis, Rape: the Price of Coercive Sexuality 95-Io8 (1977), wherein they reported that the assailants they studied exhibited behavior and attitudes that ranged from brutal violence, to callous indifference, to attempts to normalize the behavior as sex with a "new love" whom he had successfully "seduced." In cases of the latter type, the assailant sometimes even sends the complainant flowers. 
meaning, not intending to cause harm to the other, not "dangerous," are those who are most apt to avoid the stigma of being labeled a sex offender. Here issues of social position, status, and group membership can be crucial. When a decision maker sees his or her own characteristics and experiences mirrored in the characteristics, situation, and conduct of the alleged offender, and says "That could be me," the likelihood increases that the accused's intention and motive will be assessed as either positive or neutral, and the allegation will be deemed unfounded or the case will be closed without prosecution. When the conduct either is or is seen to be ambiguous with respect to intention or motive, demographic markers become especially important. When intention or motive appear ambiguous, a decision maker more easily rationalizes a decision not to proceed, despite a solid case on the whole of the evidence, by concluding that if the case went to trial, the trier of fact would be unlikely to believe that the accuseda member of such and such a family, profession, church, social group, and so forth-could and would have committed the alleged offense or indeed any sexual offense.

This dynamic can be seen in the reasons for decision in cases decided at common law in which liability to conviction was explicitly based on a conclusion about the moral quality of the actor rather than the legality of the act. Accused who were seen to have acted contrary to law but without a venal intent or motive were often acquitted. This approach continues to be used in cases involving nonstrangers to distinguish between sexual activity that involves misadventure and poor judgment, and sexual activity that is sexual assault. The legal requirement that sexual activity be consensual is often disregarded in such cases. Discourse analysis of reasons for decision on verdicts and sentencing at trial confirms that negative or positive appraisals of the accused's intention and motives and the negative or positive evaluative connotations of words selected to describe the factual circumstances of a case tend to mirror one another. ${ }^{30} \mathrm{~A}$ decision maker's

30. Linda Coates \& Allan Wade, Telling It Like It Isn't: Obscuring Perpetrator Responsibility for Violent Crime, I5:5 Discourse \& Soc'y 499 (2004); Greg Matoesian, Representing Rape: Language and Sexual Consent (Book Review), I4:2 DisCourse \& SoC'Y 230 (2003); Susan Ehrlich, Discourse, Gender and Sexual Violence, I3:I Discourse \& Soc'y 5 (2002); Susan Ehrlich, Legal Institutions, Nonspeaking Recipiency and Participants' Orientations, I3:6 DisCOURSE \& SOC'Y 73I (2002); Susan Ehrlich, Law and the Language of Identity: Discourse in the William Kennedy Smith Rape Trial, I6:I Discourse \& SOC'y I4O (2005); Susan Ehrlich, Legal Discourse and the Cultural Intelligibility of Gendered Meanings, 
neutral or positive assessment of the "moral" quality of an accused and his conduct can result in acquittal even though the legal significance of the facts in evidence at trial points to conviction. Thus nonlegal notions about the "morality" of socio-sexual activity continue to be potent influences in decision making in sexual assault cases. Police, prosecutors, and judges are all exposed to the beliefs, attitudes, and assumptions that are prevalent in the culture, and this is reflected in the decisions they make. ${ }^{31}$

A closely related source of ambiguity and uncertainty about what is and is not sexual assault that works in tandem with, and supports rationales associated with, the seduction model arises from the present treatment of the validity of consent obtained by deception. In 1998, in $R . v$. Cuerrier, a case in which the accused failed to disclose his positive HIV status, the Supreme Court of Canada held that the use of deception to induce someone to consent to sexual activity only vitiates consent if (I) the deception or fraudulent representation has "the effect of exposing the person consenting to a significant risk of serious bodily harm," and (2) the person would not have consented had they not been deceived about the issue in question. ${ }^{32}$ A dissenting view was that any deception that induces the complainant to consent vitiates consent. ${ }^{33}$ This could include misrepresentations about promised gifts (fur coats and diamonds, for example) or the accused's employment or profession ("I am a physician, banker, engineer, chairman of the XYZ board, celebrity, rock star, . . ."), or marital status. There is apprehension, however, that the latter approach would tend to trivialize the criminal law by converting "ordinary" exaggeration and selfaggrandizement, deception and lies, into crimes. Laws criminalizing seduction by fraudulent promises of marriage were repealed many years ago in

II:4 J. Sociolinguistics 452 (2007); Clare MacMartin, (Un)reasonable Doubt? The Invocation of Children's Consent in Sexual Abuse Trial Judgments, I3:I DisCourse \& SOC'y 9 (2002); J. Luchjenbroers \& M. Aldridge, Conceptual Manipulation by Metaphors and Frames: Dealing with Rape Victims in Legal Discourse, 27:3 TeXT \& TALK 339 (2007). See also Eades, infra note Io6.

3I. Some contemporary Canadian legal academics and jurists routinely invoke "morality" rather than "legality" for persuasive purposes when discussing the interpretation and application of sexual assault law and criminal law in general. This practice merits sustained examination and critique; left unchallenged, it may tend to perpetuate traditional assumptions about gender roles, female sexuality, race and social position, and lead to discriminatory enforcement of the law.

32. R. v. Cuerrier, [1998] 2 S.C.R. 37I per Cory J.

33. Id., reasons in dissent by L'Heureux-Dubé J. 
Canada, and at present there seems to be curiously little appetite among legal professionals to resurrect such laws in another guise.

The Court's present interpretation of the law of sexual consent arguably leads to a contradiction when consent obtained through deception is at issue, however. The definition of "sexual consent" as "voluntary agreement" suggests that the agreement will be deliberately formed based on relevant information - that is, that valid consent is "informed consent." If so, duplicity with respect to any issue that influenced the decision made by a particular complainant must vitiate consent, as suggested by the dissent in Cuerrier. But, to date, the Court has declined to interpret the law of sexual consent in that manner. ${ }^{34}$ Cuerrier, discussed above, continues to govern this issue. As long as deception or fraud does not have the effect of exposing the complainant to significant risk of serious bodily harm, a complainant who agrees to sexual activity that she would have refused had she not been deceived, is deemed to have "consented." Sexual consent by individuals who are not incompetent or incapable, but merely trusting or gullible or tipsy and therefore easily deceived, or who are simply imprudent, is valid and legally effective.

That approach mirrors and arguably reinforces the widely held understanding that seduction, even if it involves some elements of deception, is not sexual assault because the seducee is a free, though not necessarily prudent, agent who makes choices about what to do in response to the seducer's words and actions. In the absence of proof beyond a reasonable doubt to the contrary - a high threshold — all sexual activity is ordinarily assumed to involve some elements of seduction and is therefore presumed to be consensual, the result of the words and conduct of both parties, either of whom could refuse to participate. These assumptions continue to be used by many decision makers to distinguish noncriminal sexual activity from sexual assault. The net effect is that many complainants are found to have "consented"- - even though the legal significance of the facts viewed through the lens of the legal definition of "consent" as voluntary agreement would show that in law they did not. When such complaints are screened by police and prosecutors using a seduction paradigm, often the result is doubt about the absence of consent. Doubt about the absence of consent based on the

34. These issues are before the Supreme Court of Canada again in R. v. Mabior, (validity of consent where accused did not disclose his positive HIV status to the complainants). Heard February 8, 2012; decision reserved. 
supposition that sexual activity always involves some elements of seduction results in nonenforcement, even when the legal significance of the material facts, properly viewed through the lens of the legal definition of "consent" as voluntary agreement, would show either that there was no agreement to the initial sexual touching or that the agreement was not voluntary. Below we revisit this phenomenon and examine the influence of the seduction paradigm on judicial reasoning and judicial practice in those few sexual assault cases that proceed to trial.

This is not the only category of criminal cases in which traditional approaches based on social mores, moral judgments, and nonlegal social assumptions about what constitutes criminality, influence case analysis and provide a shortcut to the decision. Fraud cases are a leading example. In 1993, the Supreme Court of Canada specifically prohibited the use of "innocent" intent and motive to excuse an accused charged with criminal fraud. ${ }^{35}$ Mens rea is established by proving that the accused was aware of facts indicating that the financial interests of the deceived were put at risk as a consequence. Culpability turns on the accused's awareness of the factual circumstances, not on whether the accused meant well and sincerely believed that the victim would not actually suffer any loss. Twenty years later, it remains an open question, however, how often police and prosecutors nonetheless continue to rely on their personal opinion about an accused's intent and motive to distinguish "ordinary business practice" from "criminal fraud." Canadian enforcement of white-collar crime legislation is notoriously weak. As in the enforcement of sexual assault laws, traditional approaches to analysis of the facts of everyday business transactions remain tenacious, supported by the social attitudes and personal beliefs of decision makers. Some police, prosecutors, and trial judges who exercise legal authority on behalf of the public are reluctant to apply the criminal law in a manner that condemns actors whose morals and motives are seen as "normal," representative of "ordinary" behavior.

Therefore perhaps we should not be quite so surprised to see some legal professionals and jurists assert that "sexual seduction" involving nonconsensual sexual touching should continue to be treated as a form of "normal sexual behavior," rather than as sexual assault, or argue that this is necessary to preclude "injustice" in cases involving sexual activity between young

35. R. v. Théroux, [1993] 2 S.C.R. 579; R. v. Zlatic, [1993] 2 S.C.R. 29. 
people, ${ }^{36}$ "intimates," 37 and spouses. ${ }^{38}$ Such an approach implicitly draws a line between strangers and nonstrangers and proposes different standards for members of each group_ "us" and those like us, as opposed to the "others." Criminalization of sexual activity by nonstrangers is viewed as not only inappropriate but also wholly unnecessary because, it is further opined, women and girls can and do protect themselves quite adequately from unwanted sexual overtures by acquaintances and other nonstrangers. That is a tautology, framed as an assertion of fact, which implies that all sexual activity between nonstrangers is, by definition, consensual. The argument typically proceeds more or less along the following lines:

All a woman or girl needs to do is say "No," and her spouse, friend, or partner will be able to discern her "true" wishes and desist-as has, of course, always been the case in "normal" sexual relationships between "normal" people. Kissing and touching in the absence of overt consent is normal. Anyone who wishes to resist a sexual overture can easily do so. Life would be diminished, would lose some of its magical zest, if we abandoned the subtle "art" of seduction. It's so common and harmless that abandoning it is really out of the question; in any event, seduction certainly should never be a ground for criminal liability.

In this fictional opinion piece, nonconsensual physical contact between friends and spouses is romanticized as "seduction" rather than stigmatized as an offense. Although it is fictional, the attitudes it depicts are quite real and very common.

\section{E. Tales of Seduction}

Proof of the absence of consent is difficult when a seduction scenario is available to provide an alternate theory for the case. Seduction scenarios are commonly used to characterize sexual activity as consensual when the parties know one another, regardless of the specific basis of the relationship. Used effectively by an accused or his counsel, the bare fact of a relationship can be used to suggest seduction and, in turn, consent. A simple intimation

36. As noted by Professor Stuart, for example, supra note 2I.

37. Supra note 27 (all sources); and Jennifer Koshan, the Legal Treatment of Marital Rape and Women's Equality: An Analysis of the Canadian Experience (equality effect, 20Io), http://theequalityeffect.org/pdfs/maritalrapecanadexperience.pdf.

38. See Randall, Credibility, supra note 27; Randall, Spousal Assault, supra note 27; Craig, Ten Years, supra note 27; and Koshan, supra note 37. 
that seduction may have occurred usually suffices to imply that the activity may have been consensual. This invites the conclusion that the activity was not criminal, and the accused is not liable to be convicted. In the absence of extreme violence, a seduction scenario is usually assumed to be available, even when evidence of conduct that might be realistically described as "seductive" is scanty. This is widely appreciated by complainants and assailants alike; it affects both social behavior and the reporting of sexual offenses committed by nonstrangers in a broad range of social relationships. The socio-economic circumstances of many types of social relationships give rise to differences between the status, authority, and power of the parties that facilitate use of the seduction paradigm to insinuate that the complainant may have consented. In each category below, such factors are often used to create doubt about the absence of consent.

Immigrants and refugees. Refugees and persons without immigration documents are at high risk of sexual exploitation. ${ }^{39}$ They are often poor, not fluent in the dominant language, fearful of being deported, and may work under conditions in which they are subject to the exercise of arbitrary power by supervisors. Complaints to employers or the police are rare due to fear of adverse consequences. Language barriers and inadequate resources for law enforcement and support services impede effective enforcement of the law. In the unlikely event that a case is reported and selected for prosecution, the prosecutor must anticipate that the accused will claim that he "seduced" the complainant, that she chose to engage in the sexual activity with him in response to her sexual desire for him. Her poverty may be used to insinuate that she hoped the relationship with the assailant would result in favorable treatment in the workplace or other benefits. It may even be suggested that she is a seductress who acted as the aggressor in initiating the sexual activity in an attempt to improve her circumstances by creating an allegiance with someone in a position of power and authority in the work place. ${ }^{40}$

39. Human Rights Watch, Cultivating Fear: the Vulnerability of Immigrant Farmworkers in the U.S. to Sexual Violence and Sexual Harassment (May 2012), http://www.hrw.org/sites/default/files/reports/uso5ı2ForUpload_I.pdf.

40. Seduction scenarios demonstrate the fragility of a classical liberal "consent" model based on the assumption of autonomous choices among equals. There are often disparities in power or status between the parties that affect the choices the parties make and the operation of the legal process, but these disparities and their effects are not recognized by the 
Professors and students, coaches and players, clergy and lay persons. Students, athletes, and parishioners have long been vulnerable to sexual exploitation by teachers, coaches, and spiritual mentors. In recent years, the vulnerability of those in subordinate positions within institutional hierarchies to assault by teachers, coaches, and religious and community leaders has come to be better understood. Abuse of trust, power, or authority as a means to obtain sexual access to those under one's supervision is now explicitly recognized in Canada under section 273.I(2)(c) of the Criminal Code as a circumstance in which consent is not obtained. In theory it should now be easier to characterize sexual touching by physicians and teachers, as well as by supervisors within any organizational structure, as sexual assault rather than successful seduction. In practice, however, as long as the complainant is not a minor, offenses that fall within this category remain open to interpretation through a traditional seduction lens, rather than a legal lens; many of these offenses are likely neither reported or nor prosecuted. ${ }^{41}$

Acquaintances, including "dates." Sexual activity between acquaintances is unlikely to be reported even when the potential complainant knows that she did not consent and that she was sexually assaulted. Cases that are reported but do not involve evidence of serious physical injuries to the complainant are easily (albeit incorrectly) categorized as noncriminal on the ground that, at worst, the parties failed to communicate effectively. Rephrased, this often simply means that the complainant is told that the assault was her fault, that she should have objected more vigorously, etc., etc., and that the evidence leaves room for reasonable doubt about the absence of consent. ${ }^{42}$

Members of extended acquaintance, employment, service, or family networks. A complainant who is not impoverished but who is subordinate to the assailant because of their respective social positions or the

unqualified theoretical model. Legal theorists have been aware of these limitations for many decades. Judges often ignore them.

4I. See, for example, the decision in the preliminary hearing in R. v. RHR, [2007] N.J. No. 279, Newfoundland and Labrador Provincial Court. The preliminary inquiry judge did not commit the professor to trial and dismissed the charges. For reasons known only to the prosecutor, the Crown did not appeal the decision.

42. See R. v. T.A., [2007] N.J. No. 192 (here again, the Crown failed to appeal the acquittal); R. v. Ewanchuk, [1999] I S.C.R. 330, and concerns raised by Stuart, supra note 2I. 
terms of her employment is vulnerable to ongoing sexual exploitation that may be less visible than that to which the most marginalized persons are subject. Comparative socio-economic stability and an adequate standard of living may create an appearance of order and of personal and family security that mask exploitation. In these circumstances, fear of loss of socio-economic security and stability may be manipulated by an assailant to secure the complainant's silence. Assailants may be thoroughly socialized to expect sexual compliance, deference, and silence from those in subordinate social positions, and may be shocked to be accused of sexual assault. ${ }^{43}$

Spouses or partners, married or living in a long-term partnership. Analysis of sexual consent between spouses and long-term sexual partners is often confusing for both participants and legal professionals. Extensive research in the Canadian context shows a continuing widespread and persistent tendency to imply consent on the basis of the fact of marriage or longstanding intimacy between the parties. In law, of course, consent cannot be implied, but some jurists and other legal professionals cling to the traditional but defunct belief that, by definition, marriage or a similar long-term relationship entails ongoing sexual consent. Distorted legal reasoning results. ${ }^{44}$

43. See Indictment No. 2526/20II, People v. Dominique Strauss-Kahn, 20II WL 3671880, alleging that on May I4, 20II, the accused, then President of the International Monetary Fund and widely expected to be a candidate in the French presidential campaign, sexually assaulted a hotel housekeeper in his New York City hotel suite. On August 22, 20II, the prosecutor filed a motion for dismissal of the charges; Motion to Dismiss, available at http://www.nytimes.com/interactive/20II/o8/22/nyregion/dsk-documentsand-court-filings.html?ref=dominiquestrausskahn. The complainant's credibility with respect her statements about the facts related to the alleged assault by Mr. StraussKahn was not impugned, but in the prosecutor's opinion there was reason to believe that although members of a jury might find her credible-just as the investigators had initially - she was not a reliable witness; to proceed would be to risk a wrongful conviction, hence the request for dismissal. Whether the district attorney's office is always as careful in its assessment of the reliability of its witnesses is unknown. There has been wide-ranging speculation about the role the accused's political aspirations and reputation as an avid consumer of the services of sex workers may have played in these events and the aftermath.

44. See R. v. RV, [200I] OJ No. $5 \mathrm{I} 43$ (Ont Ct J); for discussion and case history, see infra, note 49 . 
F. Seduction Paradigms and Case Analysis in Police Stations and the Courts

When a seduction paradigm is used to analyze a sexual assault case, the parties' conduct is normalized and the factors of power and de facto control highlighted above are rendered apparently insignificant. Ewanchuk ${ }^{45}$ illustrates this extremely well. The evidence showed that the young woman not only did not consent to sexual contact with the much older, larger, and heavier potential employer but told him to stop not merely once but three times. Nonetheless, the trial judge and two of three appeal judges found support in the evidence for the possibility that Ewanchuk may have interpreted her behavior as consent. The acquittal was upheld at the first level of appeal, even though on the facts as found at trial, the defense of belief in consent was unavailable as a matter of law, pursuant to both statute and common law. The alacrity with which these three jurists all concluded that the accused may have believed the complainant consented suggests they recognized that in the same circumstances they might have also believed she consented. That, of course, was not the legal question they were required to answer, but this does explain why these jurists viewed the accused's conduct as "normal," not "criminal."

The subsequent unanimous decision by the Supreme Court of Canada, granting the Crown's appeal and entering a conviction on the basis of findings of fact at trial, was viewed with dismay in some circles as a feminist coup d'état; dire warnings were issued by some journalists and the occasional academic, as noted above, predicting widespread criminalization of "normal sexual behavior," including "seduction." 46 Questions in the minds of many vocal critics of the Court's decision appeared to include: "Aren't there/ shouldn't there be some cases in which "No' does not really mean 'No'?" "Are our sex lives changed forever?" "Does this mean we are all rapists and sex offenders?" 47

45. Ewanchuk, supra note 42.

46. Stuart, supra note 2 I.

47. See Wright, supra note 2I, for detailed analysis of the public controversy that accompanied the progress of the case through the courts. The debate surrounding Ewanchuk as it progressed through the appeal process in the late 199os suggests it had been widely assumed that the 1992 amendments (largely codifications of existing common law), would require few changes in how sexual assault law was actually interpreted and applied in practice. Kent Roach, Due Process and Victims' Rights i7i-74 (1999), reports that view was widespread. The subsequent controversy revealed sharply divided views about 
More than a decade later, some judges continue to view the evidence in sexual assault cases through the lens of the seduction model and conclude either that "No" didn't really mean "No" or that even when it clearly did, the accused may not have realized that consent was absent, didn't mean to do anything "wrong," and should not be convicted. ${ }^{48}$ On occasion judges even suggest that if the complainant had acted differently, been more understanding of her partner's feelings, and made her wishes more obvious, there would have been no case to hear. ${ }^{49}$ This, of course, is the classic response of "blaming the victim." The seduction paradigm explains why some trial judges continue to find it so difficult to interpret and apply the law of consent and belief in consent correctly in cases involving sexual activity between individuals who are not strangers. ${ }^{50}$ The belief that conviction and criminalization is ordinarily an inappropriate outcome in a sexual assault case involving nonstrangers easily leads to resultoriented deliberation that distorts findings of fact and the legal reasoning process.

It is thus quite clear that the "No' means 'No" standard, whether that slogan is associated with the 1992 amendments ${ }^{51}$ or with those amendments as interpreted in Ewanchuk, ${ }^{52}$ has neither criminalized large segments of the population nor revolutionized sexual behavior in Canada. Nonconsensual sexual activity between spouses, partners, or acquaintances, that takes place under circumstances police, prosecutors, and trial judges do

whether the 1992 amendments should be interpreted and applied in a manner that went beyond those expectations.

48. See Randall, Credibility and Spousal Assault, supra note 27; and Koshan, supra note 37, for multiple examples.

49. R. v. RV, 200I OJ No. $5 \mathrm{I} 43$ per Wolder J. (Ct J), illustrates the tendency of some judges to find the assailee lacked sufficient sensitivity to the accused spouse's "romantic" impulses. See Christine Boyle, Sexual Assault as Foreplay: Does Ewanchuk Apply to Spouses?, 20 C.R.(6th) 359 (2004), commenting on the decision in R. v. RV, [2004] OJ No. 849 (Ont Sup Ct J), upholding the trial decision reported at [200I] OJ No. $5 \mathrm{I} 43$ (Ont Ct J). The Crown's further appeal from acquittal was dismissed, [2004] OJ No. 849 (CA); no re-trial was ordered despite findings of major errors of law in both the lower court decisions.

50. Randall, Spousal Assault, supra note 27, at I47, I79, found some judges assume consent "to exist by virtue of the existence of an ongoing intimate relationship," and "recast sexual persistence and even intrusion, as indicating 'romantic' gestures and intentions on the part of the accused."

5I. Roach, supra note 47.

52. Ewanchuk, supra note 42; Stuart, supra note 2I, in response to Ewanchuk. 
not consider exploitative in a traditional sense, is still often not seen to be a "proper" basis for a criminal conviction. ${ }^{53}$ Case outcomes continue to depend largely on the attitudes and beliefs of counsel and the trial judge, not the law. ${ }^{54}$ Many poorly reasoned judicial decisions likely reflect perspectives on the facts of the case that were initially suggested by counsel. ${ }^{55}$ The personal attitudes of police and prosecutors also influence decisions about whether charges are laid and cases proceed to trial. Enforcement of the law is wholly at the discretion of the police and the Crown prosecutor's office; prosecutors do not routinely appeal acquittals even when an appeal is available in law. Resources, workloads, and public priorities all play a part in these decisions. In rare cases, a judge may enter a stay of prosecution on the ground of abuse of prosecutorial discretion, but to date, Canadian judges have not been prepared to direct that a prosecution proceed. ${ }^{56}$

53. Boyle, supra note 49; Randall, Credibility and Spousal Assault, supra note 27; Craig, Ten Years, supra note 27; Derynck, Lacking Change, supra note 27. See also the extensive examination of spousal assault cases in Koshan, supra note 37. Spousal assaults that do not involve traditional forms of violence and exploitation rarely result in charges or proceed to the trial stage.

54. Ruthy Lazar interviewed prosecutors and defense counsel in wife/partner rape cases in Ontario, and found they "presume consent to sex in intimate relationships, which, in turn, shapes the way those players construct and litigate wife rape." Ruthy Lazar, Negotiating Sex: The Legal Construct of Consent in Cases of Wife Rape in Ontario Canada, 22 Can. J. Women \& L. 329 (20io) at 333. Jennifer Temkin \& Barbara Krahé, Sexual Assault and the Justice Gap: A Question of Attitude (2008), report similar outcomes in their studies of the attitudes and beliefs of legal professionals in the United Kingdom and in studies by others undertaken in other jurisdictions.

55. To achieve the balanced and independent perspective on the law and the facts required for sound decision making, judges may need the assistance of counsel for an intervener in public interest, counsel for the complainant, and a legal reasoning critic employed by the court to vet and critique draft judgments. All three would bring distinct perspectives to the proceedings and the deliberation process. Judges need resources and support of this type in cases in which counsel for both parties, acting in complete good faith as officers of the Court, unwittingly advocate analyses that misrepresent the law. See Vandervort, Legal Subversion, supra note 20, at 150-52; and Lucinda Vandervort, Access to Justice and the Public Interest in the Administration of Justice, 63 U. NeW BRUNSWICK L.J. I25, at I40-4I, (2012).

56. Prosecutorial discretion and authority must uphold the fundamental constitutional principle of rule of law and be exercised in a quasi-judicial manner. This leaves a broad margin for the exercise of discretion in enforcement of the law. See Robert J. Frater, Prosecutorial Misconduct (2009). 
G. The Impact of Slogans on Social Expectations and Legal Consciousness

In view of the persistent pattern of nonenforcement, even in cases involving the clear refusal of consent, it is ironic that the slogan "No' means 'No" was so strongly linked in the minds of many with the I992 amendments to the sexual assault provisions of the Canadian Criminal Code. Affirmation of the legal right to refuse sexual activity was a priority for activists in 1992; the slogan appears to have been adopted and widely used in the belief that it was a singularly effective means of summarizing a key aspect of what many activists believed the law, as amended, would require. Hindsight shows that to characterize the gist of the law in that manner lends tacit support to the deeply embedded but defunct notion that there is an onus on complainants to protest, to resist, and to do so in a manner that is credible. ${ }^{57}$ That is the irony. Users of the slogan unwittingly support the application of the seduction paradigm whereby failure to resist an assault, or resist effectively, functions as "consent"; the slogan masquerades as progressive advocacy while covertly perpetuating traditional mores.

The widespread popularity of the slogan is likely attributable, in part, to the fact that it is so innocuous on its face. Of course "'No' means 'No'!" The slogan states the obvious and thereby merely affirms what "right-thinking" people do not dispute. ${ }^{58}$ The slogan could therefore be used to garner broad support for the 1992 amendments on the assumption that the only individuals who would be caught out on the wrong side of such a proposition are "sexual deviants" and "true rapists" — "others," not "us." Strongly held, that assumption has socially discriminatory effects; the sexual assault laws are more often and more easily enforced in cases involving accused

57. See R. v. Ewanchuk, [1998] AJ No. I50 (ABCA) at 9 ฯ 58-59, in which Fraser CJC, writing in dissent, notes "the apparent unwillingness by some to let go of the debunked notion that unless a complainant physically resisted or expressed verbal opposition to sexual activity, an accused was entitled to assume that consent existed.”

58. Kent Roach reports that in 1992, the criminal defense bar did not object to codification of a requirement that an accused take steps to ascertain consent that were reasonable in the circumstances known to him; see Criminal Code, s.273.2(b). Roach reports that "defence lawyers did not object because they were confident that 'judges and juries impose their own inherent objective standards' (Canada, JLAC, 2I June I992, 5:I2-I3)”; Roach, supra note 47, at 174. Defense lawyers were clearly correct; see Lucinda Vandervort, "Too Young to Sell Me Sex!?"Mens Rea, Mistake of Fact, Reckless Exploitation, and the Underage Sex Worker, 58 Crim. L.Q. 330 (20I2). 
who are seen as "other" and whose sexual and interpersonal relationships are presumed to be different from "ours." In cases involving spouses and intimates, this same assumption encourages decision makers to conclude that enforcement of the sexual assault laws is inappropriate or improper even when, as a matter of law, the sexual activity is sexual assault. Such reliance on extra-legal criteria and personal norms is common, effectively privatizes the exercise of judicial discretion, and commonly leads to legal errors. Empirical research and anecdotal evidence shows that this same phenomenon affects both police work and prosecutorial decision making in many jurisdictions. ${ }^{59}$

Decisions show that two decades after enactment of the 1992 amendments, traditional views about "normal sexual behavior" are still influential and continue to place an onus on the complainant to object to unwanted sexual touching. When a decision maker, whether policeman, prosecutor, or judge, believes gratuitous nonconsensual sexual touching is a "normal" form of interaction - and therefore must surely be prima facie "lawful," as the reasoning goes - often little or no attention is directed to whether the complainant affirmatively consented, communicated voluntary agreement, or said "Yes" and did so voluntarily. Similarly, when it is alleged that affirmative consent was communicated but was not voluntary, a decision maker who views and interprets the facts through a traditional seduction lens and mentality is unlikely to find consent to be vitiated and invalid in the absence of evidence of overt exploitation such as blackmail, extreme violence, or threats of violence. Surprisingly, even in cases where extreme violence or blackmail is used to coerce cooperation, an appeal by the Crown may be required before a conviction is entered. ${ }^{60}$ When evidence of overt exploitation is not present, assaults are often not reported and rarely lead to charges, proceed to trial, or result in a reported

59. Refer again to the sources offered supra in note 6 , as well as the sources and commentary supra in note 43 .

6o. See R. v. MacFie (BS), [200I] 277 AR 86 (CA), reasons per McFadyen JA [MacFie]; and R. v. Stender, (sub nom R. v. S (DG)), [2004] 190 OAC I27, affd [2005] I S.C.R. 914. In each case, a panel of three Court of Appeal judges allowed the Crown's appeal from the acquittal at trial and entered a conviction on the basis of the findings of fact at trial. See Lucinda Vandervort, Honest Beliefs, Credible Lies, and Culpable Awareness: Rhetoric, Inequality, and Mens Rea in Sexual Assault, 42:4 Osgoode Hall L.J. 625, at 629-32 (2005), for analysis of MacFie. 
decision. ${ }^{61}$ In short, the "seduction" model is not only far from extinct, but thriving, while the sexual assault laws are seldom enforced.

In Canada, the cause of these phenomena is not the substantive law. Nonenforcement of the sexual assault laws occurs because as a society we choose nonenforcement, just as large numbers of us choose to commit sexual assault. The attitudes and beliefs of ordinary Canadians, police, prosecutors, and judges determine how decisions about sexual activity are made, whether offenses are reported, and how allegations are handled by the criminal justice system. ${ }^{62}$ The sexual assault laws, as such, are well designed and, when properly interpreted with guidance from common law and constitutional principles, are fully adequate to protect the personal sexual integrity of persons in Canada. The problem arises from the commission of a large number of sexual assaults combined with low and extremely selective reporting and enforcement of the sexual assault laws. This was the basic problem twenty-five years ago and remains so now. Yet judges and other professionals working in the criminal justice system can easily acquire a good working knowledge of sexual assault law, and some clearly do.

The present widespread failure either to comply with or to enforce the sexual assault laws is therefore reason for dismay. The gap between the "legal definitions" and "social definitions" of consent and sexual assault was identified twenty-five years ago as a key impediment to correct interpretation and effective enforcement of the sexual assault laws. ${ }^{63}$ Shortly thereafter the function of mistakes of law in legal reasoning in sexual assault cases was analyzed, and it was argued that the criminal responsibility of accused in sexual assault cases is subject to the same general principle that applies to accused generally: that ignorance of the law affords an accused no excuse. Mistaken beliefs about the law of consent or the legal significance of facts of which the accused was aware do not negative mens rea. ${ }^{64}$ Arguments based on law and policy were developed to demonstrate that within an egalitarian political and constitutional framework, sexual consent at common law

6I. Few alleged sexual assaults lead to a contested trial and verdict with reasons for decision. Some of the charges laid are disposed of by a guilty plea and plea bargain. See the sources offered supra in notes 3, 5, and 6, and the discussion in notes 3 and 5 .

62. Refer again to the sources offered supra in note 6 , and to the sources and commentary supra in note 54 .

63. Lucinda Vandervort, Enforcing the Sexual Assault Laws: An Agenda for Action, 3:4 Resources for Feminist Res. 44 (1985).

64. See Vandervort, Mistake of Law, supra note I. 
requires affirmative consent, the actual communication of voluntary agreement. ${ }^{65}$ By 1999, all those propositions had been affirmed by Parliament and the Supreme Court. ${ }^{66}$ In particular, in Ewanchuk, the Supreme Court affirmed much of the jurisprudence on consent developed in $M$ (M.L.), ${ }^{67}$ Park, ${ }^{68}$ and $E s a u,{ }^{69}$ construed the 1992 amendments (which codified the definition of consent and the bars that curtail reliance on the defense of belief in consent), and reversed the decision on the ground that, like the accused, two of the three justices presiding in the Court of Appeal were mistaken in their interpretation of the law of consent. ${ }^{70}$

After the decision in Ewanchuk, some observers anticipated that enforcement patterns would gradually change to reflect the law, yet empirical studies show that enforcement patterns do not appear to have changed significantly. Anecdotal evidence points to the same conclusion. The lack of significant change in the types and proportion of offenses actually reported and prosecuted appears to result from the continuing influence of nonlegal factors-cultural paradigms, and narratives, assumptions, attitudes, and beliefs about "normal" sexual activity—on the decisions made by complainants, police, prosecutors, trial judges, and jurors. ${ }^{71}$ Part II identifies the practices that continue to permit nonlegal factors to influence legal decisions about sexual consent, and proposes a solution.

\section{SOLUTIONS}

A. The Way Forward: A Different Cultural Paradigm or the Rule of Law?

The process of mapping legal criteria onto the facts of a case is crucial for decision making. At present, the outcome in the typical sexual assault case is largely determined by the interpretative paradigm used to make sense of

65. Id.

66. See Criminal Code, supra note 8; and Vandervort, supra note 8.

67. R. v. M. (M.L.), [1994] 2 S.C.R. 3.

68. R. v. Park, [1995] 2 S.C.R. 836.

69. R. v. Esau, [1997] 2 S.C.R. 777.

70. R. v. Ewanchuk, [1999] I S.C.R. 330.

7I. Canadian decision makers continue to rely heavily on "common sense," not law. The working assumption appears to be: "reasonable people don't need a lot of guidance by legal rules and procedures." This attitude is apparent in the handling of sexual assault cases throughout the criminal justice system. The combination of "common sense" and "morality" threatens to take us back, way, way back, to the future. 
the facts in social and cultural terms, rather than by law and legal criteria, because the paradigm often dominates the mapping process used to analyze the evidence. ${ }^{72}$ The mapping process includes selection of the legal questions to be asked, identification of the material facts, and determination of the order in which legal questions are asked and answered. If a cultural paradigm is permitted to shape the process of mapping legal rules and criteria onto the facts, the paradigm used to make sense of a case as a narrative or story determines the outcome. ${ }^{73}$ This leads to decisions made in the absence of thorough legal analysis, as the paradigm and the mapping process it suggests provide a shortcut to the conclusion. The result is rule by cultural norms, not by law. ${ }^{74}$ If the objective is to bring the rule of the law to the interpretation of sexual consent, the reasoning process must be structured to ensure that essential legal questions are asked and answered. The process used to map the law onto the facts must accurately and reliably: (I) identify the material facts and select, interpret, and apply legal rules to those facts; (2) preclude overt or covert reliance on nonlegal norms and definitions; and (3) affirm relevant principles, values, and objectives, including the principle of sexual self-determination. ${ }^{75}$ This requires a different approach to the mapping problem from the one commonly used in sexual assault cases, which permits cultural narratives, stock stories, and nonlegal norms, such as those embedded in the seduction paradigm, to influence interpretation.

At present, the seduction paradigm has a central place in professional and public legal consciousness. It influences our conceptualization of sexual consent and our beliefs about how sexual consent and refusal are communicated. Individual sexual conduct both reflects and reinforces entrenched

72. From Jerome Frank to the present, a rich literature documents and analyzes the use and abuse of story telling and narrative, hunch and intuition in legal decision making.

73. For another example of this phenomenon at work in a related context where assumptions about gender and sexual roles were crucial, see Lisa Sarmas, Storytelling and the Law: A Case Study of Louth v Diprose, I9 Melb. U. L. Rev. 70I (1993-1994). Chameleonlike, the "facts" of Louth $v$. Diprose can be selectively highlighted and construed to suggest either unjust enrichment or harassment and stalking, depending on the narrative selected.

74. Trial counsel are familiar with these tools.

75. These may be common law principles or those used to frame the legislation. The Preamble to Bill C-49 refers to ss. 7 and Is of the Canadian Charter Of Rights and Freedoms, Part I of the Constitution Act, I982, being Schedule B to the Canada Act 1982 (UK), I982, c.II, thereby invoking the principles of equality and fundamental justice as a justification and framework for attainment of the stated legislative objectives of the 1992 amendments; see Bill C-49, supra note Io; and Vandervort, supra note 8. 
"folk-ways" and social expectations that normalize sexual assault. Sexual conduct is therefore unlikely to change unless the sexual assault laws are vigorously enforced or those mutually reinforcing social and cultural elements are replaced by widespread adoption of an alternative cultural paradigm and different behavioral norms. To thrive and become entrenched in public and professional consciousness, any new paradigm would need to serve mutually reinforcing social, cultural, and psychological functions, just as the elements of the old paradigm do.

It may be tempting to believe that a new cultural paradigm ${ }^{76}$ designed to support the definition of "consent" as voluntary agreement would transform cultural assumptions, beliefs, and attitudes toward sexual behavior, vastly reduce the incidence of sexual assault, encourage reporting, and alter the decision-making processes in sexual assault cases. But reliance on that option might require extreme patience and resignation; change in gender norms could prove to be exceedingly slow.

Another option is to set cultural paradigms firmly to the side-as a subversive distraction in a diverse and multicultural society where traditions and sexual tastes and practices differ-and focus on renovating the processes commonly used in legal analysis to secure implementation of legal norms, the rule of law. The law purports to protect sexual selfdetermination for all individuals. Why not use the rule of law to implement that objective more effectively, and leave cultural tastes and civil society to evolve as they may . . or may not? ${ }^{77}$ The two options can be pursued in

76. An alternate paradigm would include a conceptualization of sexual consent that is correct in law, a shared understanding of how sexual consent and refusal are communicated, and a new behavioral model for the initiation and conduct of sexual relationships that applies in all contexts, including those in which nonstrangers, acquaintances, family members, and intimates interact. Writers could create a new vocabulary of erotic images and perhaps reclaim and transform the working meaning of "seduction" by telling stories about gratuitous nonconsensual "groping" in terms that reveal its often foolish reality. Such stories could help assailees to hold their experience of assault at a psychological and emotional arm's length as the assailant's project, not one the assailee "caused" by enticement. The powerful cognitive, emotional, and social dynamics of seduction and its variations, explored above, provide a partial explanation of the current low rates of reporting for nonstranger assaults and a basis for understanding and responding to "victim blaming" and "internalization of responsibility" for assault by assailees. The latter are discussed, with reference to the psychological literature, by Randall in Credibility, supra note 27, at 415-33.

77. Those who try to use state authority to curtail violence and exploitation linked with traditional gender roles should have no illusions, however. Vulnerable people often avoid 
tandem, but this article focuses on identifying the analytic steps and judicial practices required to ensure that legal reasoning in sexual assault cases is based on legal norms and definitions, not on the seduction paradigm and the beliefs, attitudes, and assumptions that paradigm supports.

B. The Impact of Paradigms in Legal Analysis and Judicial Practice

Analysis of individual cases provides evidence of how paradigms and stock stories affect legal analysis. Nonstranger assaults are an especially fruitful subject of analysis precisely because these assaults, though common, are rarely reported or successfully prosecuted. It is quite apparent from scholarly analysis of reported cases, cited above in Part I, that cultural norms, not legal norms, dominate in the "regulation" of sexual assault. Nonstranger sexual assaults provide useful evidence of the subversive operation and impact of cultural paradigms in legal decision making. This also has implications for cases in which the assailant is a stranger or is viewed as "other." When an assailant is not a stranger, not "other," and is assumed to have engaged in so-called "normal" sexual behavior, the assumption is easily made that the complainant may well have agreed voluntarily. This invites perverse acquittals. At the same time, stranger assailants are disadvantaged by cultural paradigms that invite decision makers to assume the complainant did not voluntarily agree to sexual activity. This increases the risk of wrongful convictions. The "us"/"them", "acquaintance" or "intimate"/"other" dichotomy facilitates both forms of discrimination. A more

relying on state agencies for protection because those agencies have proven to be ineffective. In contemporary North America, battered and abused women and girls, like undocumented refugees or the slaves of previous eras, often recognize that flight or going underground are their best options. The enactment of a substantive law is never anything more than a first step, and laws are not self-executing. The observation that the rule of law is subject to subversion by deeply embedded cultural attitudes and beliefs is hardly novel. See JAMES C. Sсотт, for example, on the myriad of means by which state attempts to alter "folk-ways" have long been subverted: Domination and the Arts of Resistance (i99o); Seeing Like A State: How Certain Schemes to Improve the Human Condition Have Failed (i998); and The Art of Not Being Governed: An Anarchist History of Upland Southeast Asia (2009). In addition, legal institutions are sometimes designed to accommodate and facilitate rather than curtail the expression of local cultural influences, including behavioral norms. That approach is used in Canada. Canadian federalism delegates authority with respect to selected subject matters, including the enforcement of the criminal laws, to the provinces. Such arrangements facilitate the diffusion of governmental responsibility and accountability. See Vandervort, Legal Subversion, supra note 20, passim. 
rigorous, thorough, and reliable approach to analysis of consent in the actus reus of sexual assault is clearly needed.

Vulnerable groups. The individuals who are most vulnerable to nonconsensual sexual touching, that is, sexual assault, include those who are (I) children, (2) asleep or unconscious, (3) physically, cognitively, or emotionally disabled, or (4) disempowered in relation to the assailant as a consequence of socio-economic relationships and conditions. Sexual activity with children ${ }^{78}$ and people who are asleep or unconscious ${ }^{79}$ is nonconsensual as a matter of law in Canada. Individuals who are disabled are often in a socio-economically dependent position and may be compliant as a result of socialization or institutionalization. Those who are cognitively or emotionally disabled may not have the legal capacity to agree voluntarily to sexual activity in any event. Janine Benedet and Isabel Grant have written at length about the issues arising under Canadian law in sexual assault cases involving complainants with disabilities. ${ }^{80}$ In recent work, they explore the impact of situation-specific variables on a complainant's ability to appreciate and agree to sexual activity. Some complainants may have capacity to refuse sexual activity in certain circumstances but lack capacity to understand and voluntarily agree (affirmatively consent) because agreement entails more complex perceptual and cognitive processes. ${ }^{81}$

The fourth group-persons who are disempowered in relation to the assailant due to socio-economic relationships and circumstances-poses analytic challenges. In particular, the distinction between legitimate and

78. In Canada the age of sexual consent was raised from I4 to I6 years of age in 2008. See Criminal Code, s.I5o.I. RSC 1985, c.19 (3rd Suppl), s.I; 2005, c.32, s.2; 2008, c.6, ss.I3, 54 .

79. "Prior consent" is a legally ineffective form of sexual consent. Sexual consent is ongoing and may be withdrawn at any time; persons who are unconscious lack the capacity to withdraw consent. For details, see Vandervort, Affirmative Consent, supra note 8, at 40I n.6 \& 424-25. But see Don Stuart, J.A.: Asserting Dogma over Reality, 84 C.R. (6th) 38 (20II) (alleging that the reasons for judgment by McLachlin CJC for the majority in J.A. constitute a "dogmatic" adherence to the rule of law).

8o. Janine Benedet \& Isabel Grant, Hearing the Sexual Assault Complaints of Women with Mental Disabilities: Consent, Capacity, and Mistaken Belief, 52 MCGILL L.J. 243 (2007); and Hearing the Sexual Assault Complaints of Women with Mental Disabilities: Evidentiary and Procedural Issues, 52 MCGILL L.J. 515 (2007).

8I. Janine Benedet, The Sexual Assault of Intoxicated Women, 22:2 CAN. J. Women \& L. 435, 459-6o (2010), citing R. v. Stender (sub nom R. v. S (DG), (Ont CA, 2004), supra note 60 , at $9 \mathbb{9} 43^{-54}$, for its analysis of voluntariness. 
abusive uses of power involving intimates and acquaintances remains illdefined in law. Formal and informal hierarchical relationships offer many opportunities for abuse of power. The Criminal Code provides that "no consent is obtained" when a complainant's participation in sexual activity is "induced" by the accused's abuse of a position of trust, power, or authority. ${ }^{82}$ Similarly, "no consent is obtained" where the complainant submits or does not resist as a result of the application, threat, or fear of physical force, fraud, or the exercise of authority. ${ }^{83}$ But the criminal justice system has tended to filter out cases involving coercion and abuse of power, trust, or authority, in the absence of evidence of extreme physical violence. Only in recent years have the coercive dynamics of abuse of trust, power, and authority by professionals, educators, coaches, and religious advisers been recognized by members of the general public and the criminal justice system. Sexual touching and other forms of sexual activity within the context of other types of relationships that involve trust, authority, and inequalities of power are not invariably characterized as criminally exploitative. ${ }^{84}$ Complainants, police, and prosecutors often treat assaults of intimates and acquaintances in contexts that do not involve the delivery of professional and quasi-professional services to members of the public, as if they belong in a separate category exempt from the criminal law simply by virtue of the nature of the relationship between the parties. ${ }^{85}$ As a consequence, members of the fourth group of vulnerable

82. Criminal Code, R.S.C. 1985, c.C-46, s.273.I(2)(c). See also supra, text at notes I4-I9.

83. Criminal Code, R.S.C. 1985 , c.C-46, s.265(3)(d).

84. Professionals who engage in gratuitous nonconsensual sexual activity are now more likely to be reported, disciplined, and criminally charged than in the past. Uncertainty still often surrounds cases of assault by a friend or relative. The challenge for assailees is compounded when friends or family members deny that the behavior is sexual in nature, view it as "hilarious," or at the other extreme, allege that the assailee is the aggressor or "enticed" and "seduced" the assailant. On the impact of social responses on assailee responses, see R. Campbell, E. Dworkin, \& G. Cabral, An Ecological Model of the Impact of Sexual Assault on Women's Health, io Trauma, Violence \& Abuse 225 (2009); D. Lievore, No Longer Silent: a Study of Women's Help-Seeking Decisions and Service Responses to Sexual Assault (2005).

85. See Ewanchuk and discussion, supra note 57. Recent studies documenting the role of extra-legal distinctions in prosecutorial decision making in England and California include: Paul Roberts \& Candida Saunders, Piloting PTWI-A Socio-Legal Window on Prosecutors' Assessments of Evidence and Witness Credibility, 30:I Oxford J. Legal STUd. IOI (2010), and Kay Levine, The Intimacy Discount, 55 EMORY L.J. 69I (2006). When welfare or social assistance agencies compete with prosecutors for public resources, prosecutors are arguably 
persons identified above- those who are disempowered in relation to the assailant due to socio-economic or situational factors and circumstances-are unlikely to be identified by the criminal justice system as persons who were "sexually assaulted" unless the assailant is classified as a "stranger."

Vulnerable assailees and the seduction paradigm. In theory, an affirmative sexual consent requirement provides equal protection of the law for the sexual integrity of everyone in all contexts, including vulnerable persons in the fourth group whose circumstances may involve multiple forms of disadvantage. A key strength of the affirmative consent requirement is that it applies without exception in all contexts. From a political and institutional design perspective, this is arguably one of its most noteworthy characteristics: universality. The requirement is congruent with fundamental principles of equality.

Affirmative consent affirms the right of all persons - even those involved in the routine activities of daily life in the home, workplace, or school — not to be touched in a sexual manner without their consent. Agreement must be communicated and voluntary. This appears to address issues of coercion and abuse of power. Properly interpreted and applied, affirmative consent clearly does offer better legal protection than the "No' means 'No"' standard to anyone who is sexually assaulted, whether by a stranger or a nonstranger. Yet, as seen above, despite that legal requirement, the seduction paradigm continues to influence legal analysis and judicial practice; many assailants continue to benefit from the equation between "consent" and the "presumption of desire" and the "expectation of deference" that ordinarily characterizes the "logic" of seduction. Deference is commonly expected and widely interpreted as consent. In addition, complainants who are physically restrained, touched in a sexual manner, and made aware that sexual cooperation is the price of release, may choose to comply with some sexual demands as a means to avoid other forms of imposed, coerced

placed in a conflict of interest whenever a sexual assault case involves an "intimate" who is economically dependent on the assailant. Local public policy may preempt the issue by preferring dispositions that keep assailees off the welfare rolls even when the effect is to return the assailee to a situation of sexual exploitation.

86. Assailees may not recognize or acknowledge the conduct as an offense. Similarly, if an offense is reported, it may not be classified as a "founded" case unless the assailee is a child, disabled, or was asleep or unconscious. 
intimacy they do not want and may even find odious. ${ }^{87}$ Traditionally, however, such scenarios were often classified by police, prosecutors, and judges as the successful seduction of a complainant who "resisted at first, then changed her mind." Viewed from the perspective of the assailee as "imposed intimacy," however, "seduction" loses its purported charm.

In practice, the efficacy of the affirmative consent standard depends on enforcement of the twofold requirement that (I) there must be an agreement, and (2) the agreement must be voluntary. When a "No' means "No"' standard is used and analysis is guided by the seduction paradigm, often no one asks whether there was agreement, and voluntariness is not analyzed but simply assumed. When legal analysis gives mere lip-service to the affirmative consent requirement, the analysis is woefully incomplete, partial, truncated. Asking the wrong question leads to the wrong "right" answer. This denies equal protection of the law to assailees.

To illustrate the difficulties that arise in analysis of sexual consent in cases involving nonstrangers, consider a hypothetical involving a refugee or immigrant who is a housekeeper assaulted at work by a member of her employer's family. ${ }^{88}$ If she does not file a police report, she is at risk of a subsequent assault. It would be naïve for her to assume otherwise, even if

87. Research with humans and other primates shows that dominance and claims of intimacy may be effectively asserted by simple physical touch, the laying on of hands; touch appears to have hormonal effects and can operate at an unconscious level to elicit a compliant, cooperative response from the person/animal touched. See B.I. Ditzen et al., Effects of Different Kinds of Couple Interaction on Cortisol and Heart Rate Responses to Stress in Women, 32:5 Psychoneuroendocrinology 565 (2007); T. Field, Touch for Socioemotional and Physical Well-Being: A Review, 30:4 Developmental Rev. 367 (2010); N. Gueguen, Touch, Awareness of Touch, and Compliance with a Request, 95:2 Perceptual \& Motor SKILlS 355 (2002); M.J. Hertenstein et al., The Communicative Functions of Touch in Humans, Nonhuman Primates, and Rats: A Review and Synthesis of the Empirical Research, I32:I Genetic, Soc. \& Gen. Psychol. Monographs 5 (2006); H. MacIntyre et al., Moving Against the Grain? Investigating the Effcacy of a Touch-Based Intervention in a Climate of Suspicion, 28:I Pastoral Care in Educ. 3 (20I0); C. McCabe et al., Cognitive Influences on the Affective Representation of Touch and the Sight of Touch in the Human Brain, 3:2 Soc. Cognitive \& Affective Neuroscience 97 (2008); D.C.F. Vaidis \& S.G.M. HalimiFalkowicz, Increasing Compliance with a Request: Two Touches are More Effective than One, IO3:I Psychol. Rep. 88 (2008).

88. The events in Strauss-Kahn (NYC, 20II) occurred after this hypothetical was created, but analogies with that case lend additional verisimilitude to the hypothetical. Speculation about the role political intrigue may have played in that case is irrelevant for analysis of the fictional-factual circumstances of this hypothetical sexual encounter. 
she told the assailant that she did not wish to participate in sexual activity with him. The assailant may believe that he "seduced" her, albeit with considerable effort, and that the only reason she abandoned her efforts at resistance and did what he demanded was because she responded to his sexual overtures and desired sexual contact with him. Or, he may recognize that he assaulted her but assume she fears loss of employment or deportation more than she dislikes sexual activity with him. In either case, he will likely assume she will not report the encounter/assault to her employer or police.

In theory the assailant could be charged with forcible confinement and sexual assault. The assailee would testify that she was confined against her will, touched in a sexual manner in the absence of her consent, and that she had no "real choice" and did not act voluntarily when she performed the sexual favors demanded of her, but solely because she was intimidated and feared rape, physical injury, loss of employment and deportation. The prosecutor would argue that: (I) in the circumstances, rape, physical injury, loss of employment, and possible deportation based on misrepresentations to immigration authorities about her conduct, were all foreseeable and adverse consequences of noncooperation; (2) she had no "real choice" other than to comply with the assailant's demands; and therefore, (3) the sexual acts she performed should be deemed to be nonvoluntary as a matter of law. If the trial judge agreed and ruled accordingly, that would establish the absence of consent in the actus reus as a matter of law. The case would not be liable to be dismissed on the ground of reasonable doubt about whether she did or did not "consent" subjectively, viewed as a question of fact. That question cannot arise if the factual circumstances are inconsistent with the prerequisites of voluntariness as a matter of law. Under present Canadian law, such evidence would enable a judge to hold either that her ostensible agreement was not "voluntary" within the meaning of section 273.I(I) or, as provided in section 273.I(3), that in the circumstances her "consent was not obtained." Both, of course, are questions of law and grounds for appeal by either the accused or the prosecutor.

That was theory. It is sound theory, squarely based on valid current Canadian law, but in practice a quite different analysis and outcome is likely in a case with these facts. If typical Canadian judicial practices ${ }^{89}$ were followed, the question that would be viewed as crucial in determining

89. See Ewanchuk, supra note 42 at 9 \ 24-40, for Major J's description of the approach to be taken to analysis of the actus reus of sexual assault (excerpts are reproduced in the text 
whether the sexual encounter was a criminal offense-whether "consent" was absent for purposes of proof of the actus reus-would be framed as a question of "fact" about whether the assailee's subjective state of mind was or was not one of "consent." Subjective consent is a state of mind in which the assailee "wants" the sexual activity to take place. 90 The best evidence about the assailee's state of mind is her testimony, but no weight will be attached to the assailee's evidence on this issue unless the evidence is credible. To assist in assessing the credibility of her evidence on this issue, the circumstances and the conduct of the parties are examined. Evidence showing that she did engage in conduct that could be interpreted as communication of consent is typically seen to be a basis for reasonable doubt that she did not subjectively consent. Failure to conclude beyond a reasonable doubt that the assailee subjectively, in her own mind, did not wish to engage in the sexual activity, requires dismissal of the case on the ground that the actus reus of the offense has not been proven.

In practice at present, such a case, if it were reported, is therefore unlikely to be classified as a "founded" case. Indeed, few such cases will be classified as "founded" by the police and selected for prosecution if the "logic" of the traditional seduction paradigm is used to guide the investigation and the precharge and pretrial analysis of the facts. The paradigm intimates that mutual sexual attraction is ubiquitous between parties who know one another and may, at any time, lead to consensual sexual contact, with or without some initial resistance. No matter how vehemently a complainant asserts that subjectively she did not consent, once there is any basis for reasonable doubt about her credibility on that issue, the case is liable to be dismissed. Unless the assailee was subjected to extreme violence or an equivalent classic form of coercion that is easily recognizable as a reason for the assailee's choice to comply, despite her wish not to, successful prosecution of these cases is difficult, if not impossible.

In most cases with facts similar to those in this hypothetical, the police and the prosecutor can anticipate that at trial defense counsel will argue that the complainant's sexually compliant conduct was the result of either

below at note I03). At present, this passage continues to be routinely cited and followed by trial judges across Canada.

9o. Id. At this stage the issue is whether the actus reus of the offense is established. Only if the actus reus is established, and therefore an offense is found to have been committed, does the question arise of whether the assailant was aware (knew or was reckless or willfully blind) that the consent was not, or might not be, voluntary. 
her "desire" for sex with the accused or her desire to obtain material or social benefits of some sort from the accused and, in any event, cannot be proven beyond a reasonable doubt to be solely the result of the factors she alleges shaped her decision to act as she did. In general, an assailee's credibility is immediately placed in doubt if her evidence is that she did not wish to participate even though her words or conduct communicated affirmative consent to the sexual activity in question. Police and prosecutors know from experience that it is difficult if not impossible to persuade the trier of fact that subjective consent was absent when the complainant could to be seen to lack credibility on that very issue. Most such complaints are disposed of as "unfounded" or not selected for prosecution because conviction is believed to be unlikely. Therefore no judge has an opportunity to hear the evidence and determine as a matter of law whether the circumstances in which the offense occurred were consistent with the prerequisites of voluntariness in the complainant. As a consequence, case screening decisions must be made on an individual, case-by-case basis, without the guidance from jurisprudence on consent in the actus reus, including voluntariness and its prerequisites, which the judiciary could develop if these cases went to trial. Without legal guidance on those issues, police and prosecutors necessarily rely on their personal beliefs and attitudes.

It might be assumed that assailees who resist, albeit "unsuccessfully," rather than cooperate or actively participate, could anticipate a different response from police and prosecutors. That is not necessarily true. Those complaints may be classified as "unfounded" or dismissed on the ground that the complainant could have chosen to resist more vigorously, must have chosen not to do so, and therefore clearly consented. The theory of the defense in such a case is grounded on the same defunct notion that bedevils the popular "No' means 'No"' slogan-that failure to resist or resist effectively is consent.

To illustrate this problem, the scenario involving the housekeeper who participates actively by performing fellatio to avoid being raped, may be contrasted with one in which the assailant approaches the complainant, holds her body against his body, touches her in sexual manner, and rubs his genitals against her body. Here she does not actively participate, but there is also no suggestion that she resisted. The charge in this case might be one count of sexual assault. Strictly speaking, however, there are two distinct offenses in this example: the sexual assault (sexual touching in the absence 
of consent) and the use of physical restraint to prevent the assailee's escape. ${ }^{91}$ In this example, she is not offered an opportunity to bargain her way out of the situation more quickly. No attempt is made to secure her complicity in the sexual activity. The former example, in which her active participation in her own degradation is demanded, arguably entails a greater affront to her personhood, autonomy, and human dignity.

Assume this second assailee files a complaint and you, as a member of the local police force, must determine whether the case is "founded." You should anticipate that defense counsel will want to know why the complainant did not refuse or resist, by means of words or conduct, at all. The fact that she did not participate actively will not necessarily make conviction more likely than in the previous hypothetical, even though the evidence shows that she neither said nor did anything and therefore cannot be said to have communicated affirmative consent. If a trial judge follows the map for analysis of the actus reus described in Ewanchuk and routinely used by trial judges across Canada at present, the outcome will turn on the credibility of the complainant's assertion that in her own mind, subjectively, she did not consent. Even if all the other aspects of the prosecution's case are established, even if the complainant's testimony is credible with respect to all of the objective factual circumstances of the case-the where, who, what, when, how-any reasonable doubt that the complainant's subjective state of mind was not one of consent, that she did not "want" the sexual contact, will require dismissal of the case. If the actus reus map described in Ewanchuk continues to be routinely used to guide legal analysis, such outcomes will continue to be common in many cases involving passive complainants even though submission is not consent under Canadian law. ${ }^{92}$ If trial judges instead determined, as a matter of law, whether there was "agreement" and, if so, whether it was "voluntary," as required by section 273.I(I), some of these very same cases would lead to convictions.

Scenarios involving forcible confinement and sexual assault appear to be relatively common in assaults that take place between members of extended

91. See State of Wisconsin v. Long, Wis.2d 92, 765 N.W.2d 557 (2009), a decision by the Wisconsin Supreme Court affirming convictions for second degree sexual assault and forcible confinement. The assailant held the assailee in a tight hug and thereby caused his penis to touch her buttocks and inner thigh. Like Canadian law, Wisconsin law requires affirmative consent; the evidence did not show that the complainant consented to either the sexual contact or the physical restraint used to facilitate the sexual contact.

92. R v. M. (M.L.), supra note 67. 
families, spouses or partners, acquaintances, and other nonstrangers. Physical restraint or presence in a shared living or work space creates an opportunity for sexual contact with or without a demand that the assailee actively participate in the sexual activity. Restraint may be direct physical restraint of the assailee's body, or control of a space or the means required to escape from a specific physical location, such as a car, a room, a building, or even an isolated location outdoors. In some cases the assailee may cooperate or fail to resist in order to terminate the sexual activity (which may have already commenced or which may appear unavoidable) as soon as possible with minimal exposure to risk of harm (which could take a variety of forms from pregnancy to infection to the enhanced psychological and physical trauma entailed by a greater degree of intimacy). In other cases, compliance or active participation may be extracted by a promise of release from confinement or restraint or manipulation of social fears, such as the threat of being denounced as a sexual aggressor or deviant, shunned by a family, workplace, or acquaintance network, fired from a job, deported from a country, or prosecuted for a sexual or nonsexual offense. The assailee may fear that revelation or discovery of the sexual activity will shatter relationships within a group or be psychologically damaging and socially destructive for other adults or children for whom the assailee feels responsible. In addition, some assailees will have been assaulted previously, perhaps on more than one occasion, and may be socialized or conditioned to comply and remain silent, having been taught that this is a "normal" and "appropriate" way to deal with a "private" matter. If the previous assault(s) occurred in childhood or adolescence, these lessons may be especially compelling. Only the naïve assailee will assume there will be no recurrence or escalation of the assaultive behavior. But many assailees will be naïve, and even an assailee who realizes she is at risk of being assaulted again, may nonetheless be paralyzed by apprehension about the unknown consequences of disclosure for herself and others. In nonstranger assaults, the assailant is often someone the assailee has been socialized and conditioned to care for and protect, even to her own detriment.

Therefore all cases in which physical restraint or control over the means of escape is used to facilitate sexual assault by limiting the choices available to the complainant should be analyzed as cases of sexual assault and forcible confinement regardless of whether active participation is demanded from the assailee. Even when the charge is limited to one count of sexual assault, the use of physical restraint or forcible confinement to impose either 
passive or participatory sexual intimacy on an assailee creates a circumstance in which valid consent is impossible, as a matter of common law and pursuant to section 273.I. Restraint and forcible confinement are inconsistent with the conditions that are essential for voluntariness, both at common law and pursuant to the statutory definition of consent as "voluntary agreement" in section 273.I. Proof that restraint or forcible confinementphysical or psychological constraints that curtail an assailee's freedom to remove herself from the situation-facilitated sexual intimacy, should suffice to establish as a matter of law that consent was absent within the meaning of section 273.I for the purpose of proof of the actus reus. ${ }^{93}$ Whether the circumstances that limited the assailee's freedom were preexisting or imposed by the assailant is irrelevant. The crucial question is whether the circumstances of the assailee at the time of the assault were consistent with the conditions required for the exercise of free and autonomous agency. By contrast, the approaches commonly used by Canadian trial judges to structure analysis of consent in the actus reus routinely result in truncation of the reasoning process and errors of law. ${ }^{94}$

\section{Proposed Judicial Practice: Analysis Guided by the Legal Definition of Consent as "Voluntary Agreement"}

If decisions in sexual assault cases are to be based on the law, rather than on cultural paradigms, judicial practice must be altered to ensure that consent is properly assessed in all cases. There is no consent or "voluntary agreement" unless there are words or conduct by the complainant that communicate agreement, and no agreement is valid unless it is voluntary. Both elements are required. To interpret and apply the definition of sexual consent codified in section 273.I, judges will need to develop the jurisprudence required to determine when a complainant's agreement to sexual activity is "voluntary," building on common law principles within a constitutional framework. At present the jurisprudence in Canada suggests that "voluntariness" requires that the assailee be "functionally autonomous," in a position to exercise volition freely among alternatives, not in a position that afforded him or her no "real" or "meaningful choice."

93. Dissociation and "frozen fear" are both common psychological responses to sexual assault; both limit an assailee's ability to resist or escape.

94. See MacFie and Stender, supra note 6o. 
In this article it is posited that unless the factual circumstances established in the evidence are consistent with the conditions the law deems to be prerequisites of functional autonomy, "free" exercise of volition, and "real" choice, any agreement communicated by the assailee with respect to the sexual activity in question must be deemed to be "non-voluntary," as a matter of law, for the purposes of determining whether the actus reus of sexual assault has been established. ${ }^{95}$ Judicial practice must be altered to ensure that this issue is determined in every sexual assault case that goes to trial.

It is therefore proposed that the judiciary adopt, and require counsel to adhere to, the following practices in all sexual assault cases:

I. The evidence adduced shall, to the extent possible, include the details of the factual circumstances of the alleged assault, including the words and conduct of the both parties, and the significance of those circumstances as experienced and interpreted by the complainant.

2. Where the evidence adduced by the prosecutor and defense counsel, or placed before the court through cross-examination or other means, does not provide full details of the factual circumstances of the alleged assault and their significance to the complainant, the trial judge shall, at public expense, appoint independent counsel whose responsibilities shall include:

(a) identifying, interviewing, and calling additional witnesses as required, including any expert witnesses the independent counsel deems appropriate,

(b) further direct examination and cross-examination of witnesses who have already testified,

(c) direct examination of any additional witnesses called, and

95. This is a question of fundamental normative politics that each jurisdiction will need to decide within the framework of its own legal system. In Canada, the question has been formally addressed in the context of cases in which the "moral voluntariness" of an accused's conduct has been at issue. The leading case is R. v. Ruzic, [200I] I S.C.R. 687 (the accused was charged with importing drugs and acquitted on the ground that in the circumstances, she had no real choice but to comply with the demands of her handler in the exporting jurisdiction; the Court held that it would be fundamentally unjust, a violation of 5.7 of the Canadian Charter of Rights and Freedoms, to convict and punish her for an act that was not voluntary, i.e., the product of a free will and a body under her control unhindered by external constraints.) Accused and complainants are in wholly different positions in relation to the offense and the criminal process. These differences may prove to be significant in the analysis of voluntariness. 
(d) participation in final argument with respect to

(i) the factual circumstances proven by the evidence,

(ii) the impact of those circumstances on the complainant, and

(iii) whether, as a matter of law, there was agreement, and whether the circumstances were or were not consistent with the prerequisites of functional autonomy and voluntariness in the complainant.

3. The judge presiding at trial shall determine:

(a) whether there is any evidence of words or conduct by the complainant that communicated agreement to the sexual activity in question, with the accused, at the time in question;

(b) where there is such evidence, whether it is sufficient evidence, if found credible by the trier of fact, to give rise to a defense of consent leading to a lawful acquittal; or

(c) whether the case is one in which, pursuant to section 273.I, there could be no valid consent as a matter of law because the factual circumstances were not consistent with the prerequisites of voluntariness in the complainant (where the question is a question of law based on the proven facts, not a question of fact). ${ }^{96}$

4. When deciding the question of law under $3(\mathrm{c})$, the trial judge shall consider all the factual circumstances that impeded or impinged on the complainant's freedom of movement or functional autonomy, or otherwise deprived her of a "real" and meaningful opportunity to refuse to engage in or be subjected to the sexual activity without apprehension of any consequences that were significant or important to her.

Use of this approach to the interpretation and application of the affirmative consent requirement will afford everyone, including members of the fourth vulnerable group - those who are comparatively disempowered in relation to the assailant as a consequence of socio-economic relationships

96. Where the evidence shows the assailant was aware of the factual circumstances that are held to be inconsistent as a matter of law with the prerequisites of voluntariness and voluntary agreement by the assailee, no defense of belief in consent is available; failure to appreciate the legal significance of facts of which one is aware is a mistake of law and does not exculpate. Lack of awareness of crucial factual circumstances would give rise to a possible mens rea defense unless the lack of awareness arose from recklessness, willful blindness, or self-induced intoxication. 
and conditions - with more effective protection by the sexual assault laws and lead to further development of the jurisprudence of voluntariness.

When the conditions required for voluntariness are compromised, the absence of consent in the actus reus is established. Similarly, no evidence that agreement was communicated or undisputed evidence showing agreement was not communicated establishes the absence of consent for the purposes of proof of the actus reus. Passivity, silence, and failure to resist do not communicate voluntary agreement. Refusal and saying "no" do not communicate voluntary agreement. Questions 3(c) and criteria proposed under item 4 may often be determinative for the outcome in cases in which: (i) there is disputed or undisputed evidence that the assailee communicated agreement or actively participated in the sexual activity, or (ii) there is reasonable doubt that agreement was not communicated by words or conduct. In such cases a judicial ruling that the factual circumstances were inconsistent with the prerequisites of voluntariness in the complainant as a matter of law will establish the absence of consent for the purposes of proof of the actus reus. Appeals challenging rulings on the questions of law will develop the jurisprudence on "agreement" and "voluntariness" and provide more guidance for police, prosecutors, and trial judges in future cases.

Comparison of the operation of the present and proposed approaches in analysis of sexual assault cases illustrates a general proposition that applies to all initiatives that attempt to use legal tools to achieve societal change. Law reform without corresponding changes in pretrial screening and judicial practice in the lower courts, and in the criteria and process used to receive and admit evidence, select facts, and select and map legal rules and criteria onto the facts, does not inevitably result in implementation of the reforms and a change in the patterns of law enforcement. Reform of substantive law, without changes in analytic approaches and practices, may not change much of anything at all. The specific changes in analytic approach and judicial practice that are crucial in this context where the objective is effective implementation of the affirmative consent requirements include:

(A) the addition of mandatory steps in the assessment of consent in the actus reus to determine:

(I) whether there is evidence of actual words or conduct that communicated voluntary agreement, and

(2) whether the circumstances established by the evidence were not inconsistent with the conditions essential as a matter of law for voluntariness in the assailee, and if so, 
(3) whether the evidence of the communication of agreement, if it were found credible by the trier of fact, would be sufficient to give rise to a defense of consent leading to a lawful acquittal, and (B) characterization of all of these questions as questions of law, not fact.

Where there is no evidence or insufficient evidence of communicated agreement, or the circumstances were inconsistent with the prerequisites of voluntariness in the complainant, then the case is one in which, as a matter of law, there was no consent; this establishes the absence of consent for the purpose of proof of the actus reus of the offense. ${ }^{97}$ Failure to decide (I) whether there was evidence of the communication of agreement, (2) whether the prerequisites of voluntariness were fatally compromised in the circumstances, (3) whether the evidence of communicated consent was sufficient to give rise a consent defense that could result in a lawful acquittal, or (4) failure to decide these questions correctly, would each be ground for appeal on a question of law.

\section{Voluntariness and Agreement as Questions of Law}

Assessment of whether an assailee's agreement was voluntary in fact presupposes that there was agreement and that the conditions the law holds to be essential for voluntariness were not compromised. It follows, on grounds of law and policy, that rulings on those questions of law are required in each and every sexual assault case. If there was no "agreement" within the meaning of section 273.I, consent was clearly absent. Voluntariness is only at issue when there was agreement. The ruling with respect to voluntariness applies a legal test to findings of fact about the factual circumstances, their significance as experienced and interpreted by the assailee, and their impact on her functional autonomy. The legal prerequisites of "voluntariness" include freedom from psychological and physical constraints on choice, a "real" or meaningful opportunity to choose to do or not to do something. $^{98}$

97. This approach should be used systematically in sexual assault cases to determine whether the material facts and circumstances proven by the evidence are ones in which there is no consent as a matter of law under any of the provisions of s.265 or s.273.I. Cf. Steve Coughlan, Annotation to R. v. Stender available at 2004 Carswell Ont 3378 (Ont. C.A.).

98. Leading Canadian cases on voluntariness as a prerequisite of valid consent by an assailee include $R . v$. Stanley (1977) 36 CCC (2d) 216 (BCCA), Norberg $v$. Wynrib, [1992] 2 S. C.R. 226, and R. v. Saint-Laurent (1994), 90 CCC (3d) 29I, [1994] RJQ 69 (CA), leave to 
The ruling on the legal question with respect to voluntariness requires an assessment of whether the circumstances are consistent with the law's understanding of the conditions that must be met if a choice or decision is to be regarded as "voluntary." The ruling is a ruling about a question of law, not a determination about whether the assailee consented or "voluntarily" agreed as a question of fact. If, and only if, the ruling on the question of law determines that the circumstances were not inconsistent with the prerequisites of voluntariness, is a decision either required or permitted about whether the assailee's communication of agreement was voluntary in fact. $^{99}$

The ruling on the question of law requires examination of whether the circumstances involved the use or threatened use of social power or physical force of any type against the complainant or her interests, broadly defined. At this stage, however, the issue is not whether coercion or other factors were the effective "cause" of an individual assailee's subsequent conduct. It is crucial to recognize that the assailee is not an accused person and is not required to justify her choices. The issue is not whether the assailee subjectively believed herself, correctly or not, to have a choice that might have enabled her to avoid compliance or participation, or why, as a matter of fact, she did whatever she did, but rather simply whether the factual circumstances as established by the evidence are consistent as a matter of law with the prerequisites of voluntariness. On grounds of legal policy, sexual consent can only be valid and legally effective when the conditions required for voluntary choice are present; if those conditions do not exist, there can be no valid consent. The claim is not that the assailee's right not to be sexually assaulted is enforceable if and only if the choices she made can be shown to have been caused by coercion or some other positive or negative external influence. ${ }^{100}$ The assailee is not an accused person asserting the defense of duress or necessity. The actual impact of the

appeal to the SCC refused 66 QAC i6on. See also Stender, supra note 6o. Stender is rarely cited, however, suggesting that the decision is not being raised in argument by counsel. In addition, pretrial case screening may be preventing some cases in which the approach used in Stender would be applicable from proceeding to trial because police or prosecutors fail to recognize that ostensible consent is arguably vitiated in the circumstances.

99. Analysis of related issues appears in Vandervort, Affirmative Consent, supra note 8, at 429-32.

IOo. When a finding that consent was not present is made contingent on proof that coercion, not desire or passion, caused the assailee to make the choices she did, many 
circumstances on the specific choice made by an individual complainant is not relevant unless the trial judge determines that the circumstances were consistent with the prerequisites of voluntariness, a question of law. This is the only instance in which voluntariness, viewed as a question of fact, must be determined.

The proposed approach acknowledges the difference between the relationships of the assailee and the accused, respectively, to the criminal law and the criminal justice process, and acknowledges the parallels between other offenses of interpersonal violence that involve domination and control and sexual assault, in which, by definition, the assailant requires the assailee to participate actively, comply, or submit. In sexual assault, it is the assailant's use of the circumstances and his control over the complainant to facilitate the assault that negatives the very possibility of valid consent in the actus reus and characterizes the conduct as criminal. The essential elements of the offense are sexual contact and contempt for the sexual autonomy of the complainant, not mere sexual contact. Sexual activity is not assault, unless the assailant disregards the autonomous equal personhood of the complainant.

Despite this, traditional case analysis ordinarily does not concern itself with whether the complainant agreed and whether the circumstances were consistent with the prerequisites of voluntariness and autonomy on the part of the complainant as the law understands "agreement" and "voluntariness" Instead, analysis of consent in the actus reus typically turns on findings of fact, not law, about the subjective state of mind of the individual complainant with respect to consent. This inevitably invites the judge, and the jurors in a jury trial, to interpret the issue of the complainant's subjective consent through the lens of the seduction paradigm, rather than the law, and to focus their attention - through that lens - on the credibility of the complainant's assertion that she did not consent subjectively. Previously we saw that in the absence of one or more of the classic forms of coercion-which are not part of the seduction paradigm-it is simply taken for granted that the words and conduct of the complainant are voluntary, in fact. The complainant is assumed to be an agent who voluntarily chooses to do what she does. Indeed this is thought to be part of the

assailees are denied effective protection of the law, as seen above in the impact of the seduction paradigm on legal decisions. 
charm of seduction. This is also the reason the complainant is so easily seen as a responsible agent who made a choice, not a "victim."

A related effect of the traditional approach to case analysis is seen at the appeal stage. When the presence or absence of consent in the actus reus is characterized as a question of fact, the conclusion at trial on that issue is ordinarily insulated from appellate review, as long as there is an evidentiary basis for the conclusion. When there is reasonable doubt that consentviewed as a question of fact-was absent, the accused is acquitted and has no reason to appeal, whereas the Crown can only appeal on questions of law, not fact. In practice, the Crown rarely appeals even when an appeal on a question of law is available. This has ensured that the appellate jurisprudence on consent in the actus reus of sexual assault remains comparatively undeveloped.

With the proposed approach, fewer cases turn on: (I) the credibility of an assailee's claim that subjectively, "in her own mind," she did not consent; and (2) findings of fact (as opposed to law) about whether she did or did not agree voluntarily. The crucial findings of fact will instead be those related to the factual circumstances of the alleged assault and the conduct of the parties. Whether those facts show that there was "agreement" and whether the circumstances are consistent with the prerequisites of "voluntariness" are questions of law. Failure to appreciate the legal significance of the circumstances and the parties' words and conduct, and failure to interpret and apply the legal meaning of "agreement" and "voluntariness" and its prerequisites correctly, are all errors of law and grounds for appeal. The net effect is to move the focus of sexual assault trials away from the credibility of the assailee with respect to whether her subjective state of mind was that of consent, and put the focus on the objective factual circumstances, the conduct of the parties, and the implications of both for the functional autonomy of the assailee. ${ }^{101}$ The proposed approach applies

IOI. The assailee's credibility with respect to objective circumstances (such as whether force was used and events related to assault) is less vulnerable to successful challenge. Multiple sources of evidence are often available to assist in proving objective factual circumstances. By contrast, conclusions about an assailee's subjective state of mind requires leaps of inference and interpretation that are far more vulnerable to reasonable doubt based on challenges to credibility of complainant. See Lucinda Vandervort, Mistaken Belief in Consent, Rape Myths, and Theories of Fabrication, (Jan. 2010) (unpublished, archived with the author), on reframing and reformulating the questions related to complainant credibility to focus on objectively observable factual circumstances, conduct, and verbal communication. 
to stranger and nonstranger assaults alike, but will have its greatest impact on the outcomes in cases involving nonstrangers. At present, in cases involving nonstrangers, context and relationship are routinely used to challenge the assailee's credibility, raise questions about whether the subjective state of mind of the assailee was or was not that of consent or desire, invoke the seduction paradigm (thereby insinuating voluntariness), and thus categorize the assault as a "private," noncriminal encounter between "intimates," a successful "seduction" with a measure of mutuality, and not rape or some other form of sexual assault.

An assailant's use of forcible confinement, restraint, or manipulation of the situational and socio-economic factors and circumstances that make the assailee vulnerable, to facilitate sexual assault, must be held to negative the assailee's personal autonomy as a matter of law. If there was no express affirmative agreement, or if the factual circumstances were inconsistent with the prerequisites of voluntariness and autonomous choice, the conclusion follows, as a matter of law, that sexual consent or voluntary agreement was absent both at common law and within the meaning of section 273.I. Under such circumstances the defense of consent is unavailable in law and may not be considered because it could not lead to a lawful acquittal. That also eliminates the need for proof of the complainant's subjective state of mind on the issue of consent as a question of fact, a requirement that has been a significant legal impediment to effective enforcement of sexual assault laws in cases involving nonstrangers. Use of the proposed approach to analyze consent in the actus reus should ensure that fewer sexual assault cases involving nonstrangers are classified as unfounded, never prosecuted, or dismissed at trial.

Ordinarily, an assailant is aware of the assailee's words and conduct and of the factual circumstances and cannot claim to have been mistaken about those facts. When an accused was aware that the complainant did not communicate agreement or was aware of factual circumstances that in law are inconsistent with the prerequisites of voluntariness in the assailee, a mistaken belief in "voluntary agreement" — that is, "consent" — is not available. To fail to appreciate the legal significance of known facts is a mistake of law, not an excuse negativing mens rea. ${ }^{102}$

One practical effect of the proposed approach is to make the defense of consent simply unavailable in law in many cases involving circumstances of 
blatant inequality between the assailant and the assailee. Strauss-Kahn, for example, was arguably such a case. Some commentators may suggest that the proposal threatens to impose unacceptable constraints on sexual "choice" and is "unworkable." It will definitely be inconvenient for those accustomed to sexual deference, but it is hardly unworkable from either a practical or a legal perspective. One inevitable consequence of its adoption will be rapid development of the jurisprudence on "voluntariness." Full implementation would also likely generate more support for measures to reduce inequality.

In cases involving nonstrangers - spouses, friends, and acquaintancesthe proposed approach will often lead to different outcomes because agreement and voluntariness will no longer be presumed. Words or conduct that communicate voluntary agreement, that is, affirmative consent, will be required in each case. Consent will "not be obtained" as a matter of law when the circumstances are inconsistent with the prerequisites of voluntariness. Cases will no longer be liable to be dismissed simply on the ground of doubts about the credibility of the complainant's claims about her subjective state of mind in relation to consent. As a consequence, many cases that are now classified as "unfounded" or not selected for prosecution will proceed to trial.

\section{E. Blind Allegiance to Traditional Judicial Practice}

At this point it is useful, though sobering, to revisit the issues raised earlier in discussion about the choices police, prosecutors, and judges make in the process of "mapping" the law onto the facts of a case. The traditional approach to analysis of consent in the actus reus of sexual assault is described by Major J. in Ewanchuk, where he stated:

... for the purposes of determining the absence of consent as an element of the actus reus, the actual state of mind of the complainant is determinative. At this point, the trier of fact is only concerned with the complainant's perspective. The approach is purely subjective....

While the complainant's testimony is the only source of direct evidence as to her state of mind, credibility must still be assessed by the trial judge, or jury, in light of all the evidence. It is open to the accused to claim that the complainant's words and actions, before and during the incident, raise a reasonable doubt against her assertion that she, in her mind, did not want 
the sexual touching to take place. If, however, as occurred in this case, the trial judge believes the complainant that she subjectively did not consent, the Crown has discharged its obligation to prove the absence of consent.

The complainant's statement that she did not consent is a matter of credibility to be weighed in light of all the evidence, including any ambiguous conduct. The question at this stage is purely one of credibility, and whether the totality of the complainant's conduct is consistent with her claim of nonconsent. ${ }^{103}$

Twelve years later, these comments are routinely quoted and followed or simply followed by trial judges throughout Canada in sexual assault cases. ${ }^{104}$ This is extremely unfortunate. The effect is to perpetuate the traditional preoccupation with the credibility of the complainant's assertion that subjectively, in her own mind, she did not consent, even though, under present law it is the communication of voluntary agreement or affirmative consent-a "yes" — that is actually required in all cases. To suggest that the trier of fact must base a decision about consent on a conclusion about the complainant's state of mind in cases in which there is no evidence of the actual communication of agreement invites serious confusion and error. In the absence of agreement, there is no consent as defined in section 273.I(I). If there is no communication of agreement and therefore no consent, voluntariness is not at issue. When voluntariness is not at issue as a matter of either law or fact, the subjective state of mind of the complainant is immaterial. The only cases in which voluntariness needs to be determined are those in which there is ostensible affirmative consent, that is, words or conduct that are essentially "yes." Ewanchuk was not such a case. To ask the wrong question is a recipe for the wrong answer. That is the case here. To inquire into the subjective state of mind of a complainant on the assumption that cases always turn on the complainant's credibility with respect to this issue, that it is always necessary either to conclude beyond a reasonable doubt that subjective consent was absent or dismiss the case, is to invite an answer based on the seduction paradigm and avoid the law. The law has better tools. They should be used.

The approach to analysis of consent in the actus reus described by Major $\mathrm{J}$ in Ewanchuk should only be used when (I) the complainant actually

I03. Id. at \\ 27, 29-30.

I04. A review of the reasons for decision at trial in sexual assault cases reported since the 1999 Ewanchuk decision was released, revealed no evidence to the contrary. 
communicated agreement and (2) the circumstances were not inconsistent with the prerequisites of voluntariness in the complainant as a matter of law, and therefore it must be determined whether the communication was voluntary as a question of fact. In Ewanchuk, refusal was communicated three times. There could be no question about the absence of consent. The appeal did not raise any issues related to consent in the actus reus. Major's remarks about consent in the actus reus were obiter; they were not generated on the basis of the adversarial appeal process. Nonetheless these remarks appear to have misled many police, prosecutors, and trial judges since I999, leading to the retention of traditional but defunct case screening criteria and practices. Reliance on old maps has predictably regressive effects. It is unknown whether there is a better example of this phenomenon in the legal literature than that provided by the influence of these passages from the reasons for judgment in Ewanchuk on decision making in sexual assault cases throughout Canada for over a decade.

The continuing influence of traditional modes of thinking and talking about consent in the actus reus may also be due in part to the considerable emphasis in public and professional legal discussions of the 1992 Code amendments and the Ewanchuk case on the slogan "No' means 'No'," which may be interpreted by some as suggesting that failure to resist, or resist "enough," is consent even though, in law, submission is not consent. By contrast, there has been comparatively little emphasis on the requirement for affirmative consent. Since 1999, judges have found it convenient to quote the above passages from Mr. Justice Major's reasons that list the elements of the actus reus ${ }^{105}$ and describe the process to be followed in assessing the credibility of the complainant's assertion that subjectively she did not consent. Each rote repetition encourages police, prosecutors, and other judges to continue to focus on the complainant's credibility with respect to her subjective state of mind and treat her credibility on that issue as pivotal— just as they did prior to the 1992 amendments to the Code and the 1999 Ewanchuk decision - without ascertaining whether the complainant actually communicated affirmative consent or voluntary agreement. Old questions, like old slogans, generate old answers—questions and answers that are now also the wrong questions and wrong answers in a significant

I05. In Ewanchuk, supra note 42, at 925 , Major J. states, "The actus reus of sexual assault is established by the proof of three elements: (i) touching, (ii) the sexual nature of the contact, and (iii) the absence of consent." 
portion of cases. Asking the wrong question in law often invites the wrong answer. In the end it involves a "mapping" problem.

Changing the effects that a substantive law will have as applied, requires changing the practices followed in legal analysis of the evidence. But trial judges did not alter their practices in response to either the 1992 Code amendments or the reasons for judgment by the Supreme Court of Canada in cases dealing with sexual consent in the I990s. The reasons for judgment in Ewanchuk in 1999 then simply reaffirmed and further perpetuated the traditional focus on the complainant's credibility with respect to her subjective state of mind. Trial judges still have not changed the patterns they use in analysis of consent in the actus reus of sexual assault to reflect the new conceptualization of sexual consent. The result is that even now, twenty years after the 1992 amendments and years after the decisions in M. (M.L.), Park, and Esau, traditional maps and schemas continue to be used to structure the legal reasoning process and make sense of the facts in sexual assault cases. Gaps in the legal rules, practices, and procedures used to make factual inferences and findings of fact about consent in the actus reus continue to be filled by nonlegal beliefs, assumptions, and generalizations, including those associated with the seduction paradigm. By contrast, implementation of the approach proposed here will require trial judges and counsel to adopt new practices in legal reasoning to ensure that the necessary legal questions are decided, in the proper sequence, and on the basis of evidence that is sufficient as a matter of law.

\section{F. Precharge and Pretrial Decision Making-Police and Prosecutors}

Whether sexual assault cases lead to charges and proceed to trial depends on the exercise of police and prosecutorial discretion. Police and prosecutors will often err in their analysis of the facts in sexual assault cases involving nonstrangers if they continue to interpret the law of sexual consent through the lens of the seduction paradigm. Old habits can be resilient. Implementation of the proposals in this article will require retraining programs for police, prosecutors, and any other personnel involved in the investigation and pretrial screening and preparation of sexual assault cases.

In law, the assailee is under no legal obligation to say or do anything. It is improper to suggest otherwise. Assailees must be permitted to do and not do whatever they believe is necessary to minimize harm to themselves in the whole of the circumstances without being deemed to have waived 
protection of their right not to be assaulted. ${ }^{106}$ On occasion, this may include lying, dissembling, or feigning desire to engage in the sexual activity the assailant demands. ${ }^{107}$ No matter what the assailee said or did, evidence of circumstances in which consent as defined in section 273.I was impossible as a matter of law, suffices to establish the absence of consent for the purpose of analysis of the actus reus, just as proof that the complainant was younger than the age of consent would.

Precharge and pretrial decision making practices used by police and prosecutors in the criminal justice system must change to reflect the law, not popular narratives, myths, beliefs, and assumptions. This has implications for interviewing and file preparation. When the initial question is not "Did you say 'No'?" or "Did you resist?" but is instead cast as an openended request to "Please tell me what happened, when, how, and where it happened, in detail, and from the beginning," the analytic focus shifts from the assailee to the conduct of the assailant, the whole of the circumstances, and the impact of those circumstances on the assailee. ${ }^{108}$ This transforms the legal discourse. The shift in rhetoric reflects the analytic shift from

I06. There are similarities between sexual consent and waiver of a constitutional right. Josephine Ross, Blaming the Victim: "Consent" within the Fourth Amendment and Rape Law, 26:I Harv. J. on Racial \& Ethnic Just. i (20I0) asserts: "the Fourth Amendment fails to recognize that subtle forms of coercion are incompatible with true consent. Both Fourth Amendment and rape law blame subjects who submit to subtle coercion, telling them they had a choice." In police misconduct trials, difficulties are compounded when defense counsel use a series of strategic questions in cross-examination to reconfigure the evidence of key prosecution witnesses and construct a narrative of police-citizen interaction in terms that appear to be consistent with free choice and voluntary compliance. See Diana Eades, Courtroom Talk and Neocolonial Control (2008), for close analysis of the linguistic strategies defense counsel used to obtain dismissal of the charges in the Pinkenba case at the preliminary hearing. The problem appears to be common in the interrogation and cross-examination of most witnesses of all ages in sexual assault cases. In recognition of the impact of cross-examination techniques on witness testimony at trial, judges in New South Wales now have an expanded supervisory role; Peter Johnson, Controlling Unreasonable Cross-Examination 2I:4 Jud. Officers' Bull. 29-33 (May 2009).

I07. See MacFie supra note 6o, and R. v. Sansregret, (1983), 22 Man R (2d) II5, rev'd (1983), 25 Man R (2d) I23 (CA), aff d [1985] I S.C.R. 570. In each case the assailee lied to the distraught and violent assailant and pretended to be reconciled with him. The effect was to calm the assailant, reduce the violence of the confrontation, and once the desired sexual activity was completed, obtain the assailee's release by the assailant.

108. Police and prosecutors should be made aware of the role nonconsensual sexual and nonsexual touching may have in asserting control and eliciting submissive cooperative behavior; supra note 87 . 
scrutinizing the conduct of the assailee to see whether she or he might have been responsible for the assailant's actions(!), to scrutinizing the whole of the circumstances, including the words and conduct of both parties, and the significance of the situation in its entirety for the assailee.

If the assailee did not say "Yes" or otherwise communicate agreement to the activity in question by her words or conduct, there is no consent. If the assailee said "Yes" by her words or conduct, or it may be alleged that she did, inquiry must be directed to the circumstances and their legal significance. Circumstances that are inconsistent with the prerequisites of voluntariness and autonomous choice will be circumstances in which the absence of consent is established as a matter of law for purposes of proof of the actus reus, even though agreement may have been communicated. This approach applies regardless of whether the circumstances in question were created by the assailant's actions or formed part of the situation in which the alleged assault took place or both.

By contrast, reliance on the "No' means 'No"” standard in legal analysis of consent invites police and prosecutors to scrutinize the assailee's words and conduct through the lens of the seduction paradigm and narrowly focus on the credibility of the assailee's testimony about her subjective state of mind. As seen above, many vulnerable persons who are sexually assaulted are intimidated or manipulated into silence and never report the assault. Those who do report should not be told they should have said "No" sooner, louder, or more often, or resisted more vigorously. Such comments reflect an incorrect interpretation of the law.

Use of the proposed approach by police and prosecutors should result in a change in enforcement patterns in sexual assault cases and, as more cases proceed to trial, further development of the jurisprudence on voluntariness. These developments may support a cultural shift on both the cognitive and rhetorical levels, which in due course, may be reflected in everyday thought and speech. The seduction paradigm may even come to be best known for its use in comedy routines that mock the capacity of human beings to believe what they want to believe. Canadians may begin to think and speak differently about voluntariness, consent, deference to power, coercion, abuse of power, and betrayal of trust in the context of acquaintanceship networks, workplaces, and families. The implications for interpretation of the law of consent in general, wherever it is shaped by deeply embedded cultural habits of claiming entitlement and deferring to power, are obvious. 


\section{CONCLUSION}

This article argues that interpretation and application of the substantive law of sexual consent must be structured in accordance with the law, not "common sense" or "ordinary reasonableness." Systematic practices must be used in the analysis of sexual consent as "voluntary agreement" to ensure that cases are decided in accordance with the rule of law, not on the basis of personal assumptions, beliefs, and attitudes, or the "logic" and "common sense" of the "seduction" paradigm. Each step taken in the process of legal reasoning must be based on application of law and legal criteria to the facts established in evidence. The correct questions must be asked, in the proper legal sequence. Unless the law is applied or mapped onto the facts of a sexual assault case in the correct sequence-one that gives priority, as necessary, to questions of law-the legal reasoning process is truncated, often resulting in erroneous conclusions caused by reliance on factual inferences based on assumptions and beliefs about the omnipresence and ubiquity of sexual seduction and its implications for complainant credibility, rather than on law and legal norms. Stories based on sexual myths, stereotypes, and cultural paradigms, whether progressive or regressive, may have a place in novels and plays, harlequin fantasies and comedy routines, but legal decisions dealing with allegations of sexual assault must be based on the systematic application of law, legal definitions, and legal norms to the facts established by evidence. The insights and proposals developed here in relation to analysis of sexual consent may have implications for the analysis of consent in other contexts.

The analyses in the article also suggest as a general proposition that the efficacy of substantive law reform is easily undermined by traditional approaches to legal reasoning. Two solutions are available. The judiciary can exercise leadership and take steps to alter the analytic practices routinely utilized in interpreting and applying the law to the extent that is required to give reliable and meaningful effect to the concepts and objectives set out in the law as amended. In the alternative, the reforms themselves can prescribe the specific sequence of analytic steps to be followed in interpreting and applying the law as amended. Without one or the other, law reform may well often fail to achieve any of its objectives that conflict with dominant cultural norms. In the case of sexual assault, established judicial analytic practices and habitual patterns of analysis, like case precedents, reflect previous conceptualizations of "consent" and must be reexamined and revised. New law, applied as if it were the "same" old law, changes little. 